\title{
OIL POLLUTION CRISIS AND RELATIONSHIP MARKETING APPROACH OF OIL FIRMS IN NIGER DELTA
}

\section{Komene Goodnews Loanyie (Ph.D) ${ }^{1}$ and Remi Chinedum Opurum (Ph.D) ${ }^{2}$}

\author{
Ignatus Ajuru University of Education, Department of Marketing, Faculty of Business \\ Studies, Port Harcourt Rivers State Nigeria \\ ${ }^{1}$ Email komenegoodnews@gmail.com
}

${ }^{2}$ Email: remiopurumchinedum@gmail.com

\begin{abstract}
Cite this article:
Komene G.L., Remi C.O. (2022), Oil Pollution Crisis and Relationship Marketing Approach of Oil Firms in Niger Delta. British Journal of Management and Marketing Studies 5(1), 39-78. DOI: 10.52589/BJMMS2HWKHPGW
\end{abstract}

\section{Manuscript History}

Received: 24 Jan 2022

Accepted: 13 Feb 2022

Published: 22 Feb 2022

Copyright $(92022$ The Author(s). This is an Open Access article distributed under the terms of Creative Commons AttributionNonCommercial-NoDerivatives 4.0 International (CC BY-NC-ND 4.0), which permits anyone to share, use, reproduce and redistribute in any medium, provided the original author and source are credited.
ABSTRACT: This study was designed to examine the extent to which relationship marketing approach of the oil firms: Shell BP, Agip Oil Company, and Elf Oil Firm have reduced the trend of oil pollution crisis in Niger Delta. A descriptive survey research design was employed in this study. The study population was 37,965,391 residents drawn from the projected population of Niger Delta states; based on which a sample size of 400 respondents was determined using Taro Yamane's sample size determination techniques at 0.5 percent level of significance. The purposive sampling procedure was employed to enable the researcher to select the representative sample elements of the population interest from the right respondents who have adequate knowledge of the study under investigation from the different strata of the study population. A structured instrument for data collection containing twenty (20) item questions was used for the study. The face and content validation of the instrument was obtained through the judgment of experts. A test-retest method was employed to determine the reliability of the instrument and the reliability index of .85 was obtained with the use of Spearman's Rank correlation coefficient. The data collected for the study were analyzed using the mean score test and the percentage test method to answered the research questions; while the inferential statistics of Pearson Moment Correlation test was used to test the null hypothesis at .05 level of significance. Results obtained revealed that "There is no significant relationship between the use of adaptive, responsive, interactive and reactive relationship marketing approach and the reduction in oil pollution crisis in Niger Delta". The implication of this finding is that the oil firms' by its relationship marketing approach was considered to lack merit of proactive improvement value to reduce the trend of oil pollution crisis, which if, not corrected with an ethical relationship based marketing consideration in a responsible manner; oil firms might experience sudden unpredicted operational interruption by the oil-bearing communities. It was recommended that oil firms should consider using more pragmatic sustainable ethical based relationship marketing approach in a responsible manner to reduce the trend of oil pollution crisis in oil-bearing communities in Niger Delta.

KEYWORDS: Oil Pollution Crisis, Relationship Marketing, and Oil Firms Approach. 


\section{INTRODUCTION}

It is a fundamental reality that relationship marketing is a socially oriented marketing activity that interactively relates two or more parties for mutual understanding and proactive advancement of a cause oriented achievement for a goal (Adujui, 2017). This implies that relationship marketing is a cause driven type of marketing practice that is guided towards the achievement of a set purpose. Without doubt, oil production firms usually relate with their customers and the host community for some important purposes to enable them achieves certain objectives. These objectives are driven by proper identification of customers' needs for the establishment of a relationship; and to search for proactive solutions that is capable of satisfying the identified needs. Based on this, modern business organizations in the recent time, especially the oil multinational firms have attempted to focus more on customers' relationship by employing relationship marketing approaches such as: adaptive, proactive, interactive, responsive and reactive approach for reasons of achieving a set goal. Utukepo (2011), adds that many oil producing firms in actual practice adopted some or all these approaches in their host communities to solve oil pollution related crisis Niger Delta.

Similarly, Doma and Kooateh (2018), asserts that relationship marketing is ethically guided by mutual decisions that aimed at sustaining and establishing positive cause guided actions. On the other hand, Chukwu (2008), view relationship marketing as a form of responsible marketing efforts employed by a firm to solve unethical social issues arising from irresponsible activities of business organizations (Aakol, 2009). According to Banu and Gonnee (2019), relationship marketing approach that concentrates on creating, improving and sustaining customers' interests for long term relation is transparent enough to sustain the wellbeing of the firm and customers (Morgan and Ruggurg, 2000). Significantly, such relationship has a socio-economic intention that drives home ethical values of the company (Funiwa,2002).

To be more exact, the motive or intention of the oil firms to avoid oil pollution for the wellbeing of the host community becomes the essence of oil firms involving in relationship marketing in its host community. This was traced to the need of solving oil pollution related issues that dealt with poor mutual relationship between the oil firms and their customers. Conventionally, this attempts to maintain the view in Adujui (2017) and Osabie (2007) who adds that relationship marketing anchors on a form of sustainable marketing mentality, which is directly concern with the marketing relationship activities of creating, improving and sustaining a common understanding, belief and sense of belonging between two or more parties for reasons of achieving a particular goal. Based on this reality, relationship marketing as associated with oil pollution creates room for conflict but not mutual understanding and peace; except certain technical marketing relationship approaches are adopted.

However, proactive adoption of the needed approaches, appears to go out of context as traced to oil pollution activities of oil firms (Shell Oil Company, Agip and Elf Oil Company), in the oil bearing communities in Niger Delta. The evidence of incessant oil pollution caused by the oil firms seems to abuse their marketing relationship with the host communities. Therefore, the relationship marketing practice of the oil firms that employs some forms of political gambits in their relationship marketing tends not to sustain the wellbeing of the consumer citizens. Thus, it is believed that such relationship marketing was conducted on unethical principles and dysfunctional abuse of socio-economic resources of the oil bearing 
community. Hence, the seeming political gambits in oil firms' relationship marketing practice also tend to cause misunderstanding or crisis on discovering such unethical intentions and abuse of the relationship process. The practice of breaching marketing relationship with the used of unwanted, harmful oil spillages and gas flaring activities has not only been extensively poisonous to the host communities, but a destructive operational practice when the approach were not sustainable.

Furthermore, the actual value of oil firms' relationship marketing in oil-bearing communities in Niger Delta was therefore, observed to have frustrated the core intention of relationship marketing, which oil spills and gas flaring activities were considered as negative elements. In this vein, oil spills and gas flaring effect on the wellbeing of the consumer citizens was not only driven by weak mutual intention, but full of conflict that resulted from oil pollution hazards. On a larger scale, the seeming endless impact of oil pollution crisis and its associated oil pollution activities might keep resulting in uncontrolled socio-economic health risk to the host community.

It is therefore, established that the absence of mutual relationship marketing may generate conflicts, which the oil firms and their host communities could be evidence in Niger Delta (Funiwa,2002). This add meaning to the view that, "firms' relationship marketing orientation is a function of relationship marketing achievement considered necessary to improve the value of a firm's objectives in a competitive environment where different production issues and service challenges exist (Chukwu, 2008)". On this note, oil firms in Niger Delta might thus, ceased to enjoy sustainable operation efficiency in their host communities if, they underrate the value relationship marketing in their operational activities.

It therefore, becomes obvious to state that oil pollution related crisis is an outcome of ineffective relationship marketing practice of the oil firms in Niger Delta environment. More transparently, the situation in Niger Delta has in the recent two decades, gave rise to "Memorandum of Understanding" which establish mutual marketing relationship between the oil firms and the host community to ease oil firms' operations in their host community.

For this and similar reasons, Osabie (2007) affirms that oil pollution has posed a serious threat to the socio-economic health wellbeing of the consumer citizens as traced to the view in Okon(2017) who observed that no proactive relationship marketing approach was substantiated by oil firms in Niger Delta to resolve oil pollution crisis. In line with this, Iba (2013), confirms that the sustainable economic means of livelihood of the host community has been frustrated with oil spills and gas flaring activities of the oil firms, which on a large scale justifies inactive relationship marketing practice of the firms that leads to crisis.

In view of these irregularities, oil firms in Niger Delta were observed to have been selfish oriented, driven with the intention to over look the socio-economic value of relationship marketing practice by benefiting from profits generated from oil pollution for the detriment or disadvantage of the host communities that suffer the socio-economic, health effect; traceable to the seeming failure of the oil firms to adopt proactive sustainable relationship marketing solution to the crisis. The basic concern of this study is to examine the extent to which the relationship marketing approach of the multinational oil firms has reduced the trend of oil pollution crisis in Niger Delta. 


\section{Statement of the Problem}

As observed in the past 3 decades, the multinational oil firms seems to overlook the importance of sustainable relationship marketing approach to oil pollution crisis in Niger Delta. This tends to imply that to the multinational oil firms, the value of relationship marketing and its approaches to oil pollution related crisis were not only underrated in actual practice, but it was completely considered not necessary in the scheme of marketing decision for profit making. Thus, the practice of ineffective relationship marketing and the underrating of its values were traced to oil firms' failure to sustain its host customers' interest when carrying out their oil exploration activities. As a result, the negative effects of the resultant oil spillage and gas flaring impact on the socio-economic health wellbeing of the locals were harmful and destructive. On a large scale, this does not only frustrate and destroyed the agricultural economic source of the people means of livelihood, but also posed harmful threats on their health condition in Niger Delta (Okon, 2017). This measure of marketing consideration was not only considered unethical, but viewed to have established some element of distrust in the operational activities of oil firms. At this point, the consumer citizens in the host communities appears to lost confidence in the relationship marketing operation of oil firms.

In view of this reality, oil firms were compelled to be driven by modern relationship marketing mentality of maintaining some high degree of ethical trust in their operational relationship marketing activities by avoiding internal conflicts associated with its production activities. To justify this, Chukwu, (2008), establishes that relationship marketing is a form of peace oriented marketing activity that create, improve and sustain mutual understanding, belief and sense of belonging or value between two parties for reasons of achieving a particular goal. Thus, relationship marketing does not create room for mutual value, but reciprocates interests between the oil firms and the host communities. To be more exact, it was not out of context in relationship marketing requirements of the oil multinational firms to give ethical attention to the welfare of the host community by employing proactive efforts to satisfy, create, improve, preserve and sustain their social, economic and health wellbeing since the host community have given oil firms - the succor to operate.

The observed failure with evidence of the related oil spills snag impact as well as the negative effects of gas flared activities on the welfare of Niger Delta people could not finally enhanced sustainable relationship marketing with the host community as traced to the destruction of the ecosystem and other related environmental values by oil firms. This is associated with the seeming endless oil pollution activities that poison safe drinking waters, fertile farmlands and quality air in Niger Delta (Romiyu and Dobayima, 2019). Thus, the situation was observed to have led to the fast growing negative trend of the relationship marketing failure which on a large scale, have caused unwanted socio-economic frustration, hardship and health hazards on the wellbeing of the natives in the host community. Such high level of socio-economic frustration and hardship were linked to the poisoning of agricultural foods, pollution of the underground waters and rivers, poisoning of marine lives leading human consumption of poisonous sea foods, and pollution of quality air in the environment (Banu and Gonnee , 2019).

To be more exact, this resulted in extensive cost of health maintenance and increase in the compounded cost of health treatment; associated with more health hazards of the locals 
whose health source and value have been poisoned with hydrocarbon petroleum substances. The limitation of the available agricultural farmland was also responsible for agricultural market failure, economic poverty and poisoning of healthy agricultural food production, which still appears retrogressive, capable of destroying the fecund agricultural source of the people means of livelihood. For this and similar reasons, Ekpu (2010), considered that effective and efficient use of adaptive, proactive, interactive, reactive and responsive relationship marketing approach might be useful for oil firms in Niger Delta. Esedwuo(2008), confirms also that oil firms has not ceased causing oil pollution crisis in Niger Delta following the increasing trend of negative oil spills and gas flaring impact generated by oil firms. Evidence of dysfunctional relationship marketing practice showing a sour relationship between the oil firms and the host communities triggered complaints and violent anger against the oil firms.

This gave rise to rhetoric question, "Asking if the oil firms' adaptive, proactive, interactive, reactive and responsive relationship marketing approach could reduced oil pollution crisis in Niger Delta. In order to proffer answers to this question, this study seeks to examine the extent to which oil firms' relationship marketing approach has reduced the trend of oil pollution crisis in Niger Delta.

\section{Aim and Objectives of the Study}

The main aim of this study is to examine the extent to which the Multinational Oil Firms' relationship marketing approach to oil pollution crisis has reduced the trend of violent Crisis in Niger Delta. In order to achieve this aim, the following specific objectives are considered relevant.

(i) To examine the extent to which oil firms' "Adaptive Relationship Marketing Approach" to oil pollution crisis has reduced the trend of oil facility destruction in Niger Delta.

(ii) To find out the extent to which oil firms' "Interactive Relationship Marketing Approach" to oil pollution crisis has reduced the trend of kidnapping oil company workers in Niger Delta.

(iii) To examine the extent to which oil firms' "Responsive Relationship Marketing Approach" to oil pollution crisis has reduced the trend of hostile demand for payment of oil spills damages in Niger Delta.

(iv) To examine the extent to which oil firms' "Reactive Relationship Marketing Approach" to oil pollution crisis has reduced the trend of government hostile attack on the host communities by soldiers in Niger Delta. 


\section{Research Questions}

The following research questions were used as guide in this study.

(i) To what extent does the oil firms' adaptive relationship marketing approach to oil pollution crisis, reduced the trend of oil facility destruction in Niger Delta?

(ii) To what extent does oil firms' interactive relationship marketing approach to oil pollution crisis reduced the trend of kidnapping oil company workers in Niger Delta?

(iii) To what extent does oil firms' responsive relationship marketing approach to oil pollution crisis reduced the trend of hostile demand for payment of oil spills damages in Niger Delta?

(iv) To what extent does oil firms' reactive relationship marketing approach to oil pollution crisis reduced the trend of government hostile attack on the host communities by soldiers in Niger Delta?

\section{Research Hypotheses}

Based on the fore going questions, the following hypotheses or propositions were made. However, they stated in null form.

Ho1 Oil firms' "Adaptive Relationship Marketing Approach" to oil pollution crisis does not, significantly reduced the trend of oil facility destruction in Niger Delta.

Ho2 Oil firms' "Interactive Relationship Marketing Approach" to oil pollution crisis does not,

significantly reduced the trend of kidnapping oil company workers in Niger Delta.

Ho3 Oil firms' "Responsive Relationship Marketing Approach" to oil pollution crisis does not,

significantly reduced the trend of hostile demand for payment of oil spills damages in Niger

Delta.

Ho4 Oil firms' "Reactive Relationship Marketing Approach" to oil pollution crisis, does not significantly reduced government hostile attack on the host community by soldiers in Niger Delta. 


\section{Significance of the Study}

The significance of this study anchors on the benefits that the employed relationship marketing approaches to oil pollution crisis in Niger Delta could also be used in other locations in the world. It will also provide better understanding about the extent to which oil firms' relationship marketing approaches in Niger Delta - Nigeria has reduced the rate of oil pollution crisis.

It will also help the relationship marketing managers and the management of the oil firms to have better understanding of the negative implications of oil pollution crisis on the wellbeing of the firms and the best ways out to improve on its irresponsible relationship marketing practice. In addition, Oil firms will by this study understand whether or not if, they are improving on their relationship marketing approach employed in Nigeria and Niger Delta respectively. Significantly, the study will also afford the host community and the management of the oil firms to gain new knowledge on how to practice relationship marketing that dealt with oil pollution crisis. To a large extent, this study will also afford the management of oil firms the opportunity to adopt more proactive relationship marketing approach that will help solved oil pollution related crisis in other part of Nigeria and the world at large. Indeed, this will add value to the standard of living in the oil bearing community by making life more meaningful. On the other hand, the study will assist and enable students, scholars and researchers to understand more about the usefulness of relationship marketing and its soft approach to resolve oil pollution crisis. Without doubt, the study will serve as a point of reference in the review of related literature on related studies for students, scholars, and researchers.

\section{Conceptual View of Relationship Marketing Approach to Oil Pollution Crisis}

Relationship marketing view of oil pollution crisis is traced to the failure of oil firms and their inability to avoid oil spillage and gas flaring activities on the physical environment. Relationship marketing approach by this concept shows how the relationship marketing technique of the oil firms could influence sustainable prevention of "oil pollution crisis" in oil-bearing communities in Niger Delta. This add meaning to the finding in Akinbuwa, 2008). who opined that oil spillage and gas flaring activities of the oil firms has been responsible for oil pollution crisis, which resulted from the demand for payment of oil-spills damages, associated with oil facility destruction in Niger Delta. Thus, project the view in Williams (2000), who adds that oil pollution crisis, is an evidence of oil pollution driven conflict arising from ineffective relationship marketing between the oil firms and the host community. In view of these irregularities, oil firms in Niger Delta were observed to have been selfish, driven with the intention to over look the socio-economic value of relationship marketing.

On the other hand, "Oil Pollution Crisis" is considered as ecological evidence traced to the destruction of the ecological system; which in aggrieved reaction leads to oil facility destruction, hostile demand for payment of oil-spills damages, and aggressive kidnapping of oil company workers in oil-bearing community (Osabie, 2007). In this vein, the intention to placate or soothe oil pollution crisis tend to measure the extent to which proactive, responsive, interactive, and reactive relationship approaches has reduce oil pollution crisis. 
On this note, the relationship between socio-economic health threats caused by oil pollution and a responsible relationship marketing practice of the oil firms appear not to have common bearing in the relationship marketing approach adopted by the oil firms. Okon(2017), confirms that oil pollution crisis and the solution approach employed by oil companies has been weak enough to reduce the increasing level of conflicts in Niger Delta. In line with this, relationship marketing is the marketing activities of oil firms that deal with the application of ethical trust, and the mutual relationship design to protect, sustain, improve and preserve environmental values for living and non-living things (Funiwa,2002). Conceptually, the belief about relationship marketing as concern with environmental protection is hinged on the marketing activity of oil firms that focused on best ways of protecting, sustaining, improving and preserving the environmental wellbeing of the society. This conceptual view is driven by environmental oriented relationship marketing, which directs its attention to the activities of a societal marketer who is focus on the sustainability and protection of the consumers and the society socio-economic wellbeing.

To be more exact, the absence of the view to sustain, improves, preserve and protect the consumers and the host community's socio-economic wellbeing might results in oil pollution crisis. Osabie (2007), defined oil pollution crisis as the conflict that arise from an existing evidence of incessant oil spills and gas flaring activities of the oil firms in the oil-bearing community. This adds meaning to the fact that oil pollution hinged on the release of harmful petroleum substances that poisons the land, water, and air (Aakol, 2009). The economic protection oriented mentality concerning oil pollution is thus, driven by environmental oriented marketing relationship, which seeks to avoid oil pollution crisis. Thus, the environmental relationship marketing concept which holds that "Marketers should search for the environmental marketing relationship needs of the society and adopted best ways of satisfying them, effectively and efficiently; to ensure proper protection, sustainability, improvement and preservation of environmental benefits and values for living and non-living things"(Morgan and Ruggurg, 2000). It further contended that any relationship marketing that is concern with the security of environmental values is a facet or element of societal marketing that anchor its guiding force on ecological or green marketing practice deduced from ethical oriented relationship marketing decision.

Conventionally, the avoidance of oil pollution crisis as associated with oil pollution hazard is traced to societal marketers' view of ensuring a responsible relationship marketing, and its supportive marketing activities to secure sustainable green marketing practice that is guided by the desire to protect, sustain, improve, and preserved the wellbeing of the ecosystem (the flora and fauna), for the good of the consumer citizens in the oil-bearing community.

\section{Operational Conceptual Framework}

Operational - conceptual link between the Predictor and Criterion Variables, showing how the predictor variable influenced the criterion variables in oil pollution crisis reduction. It is presented in the following order. 


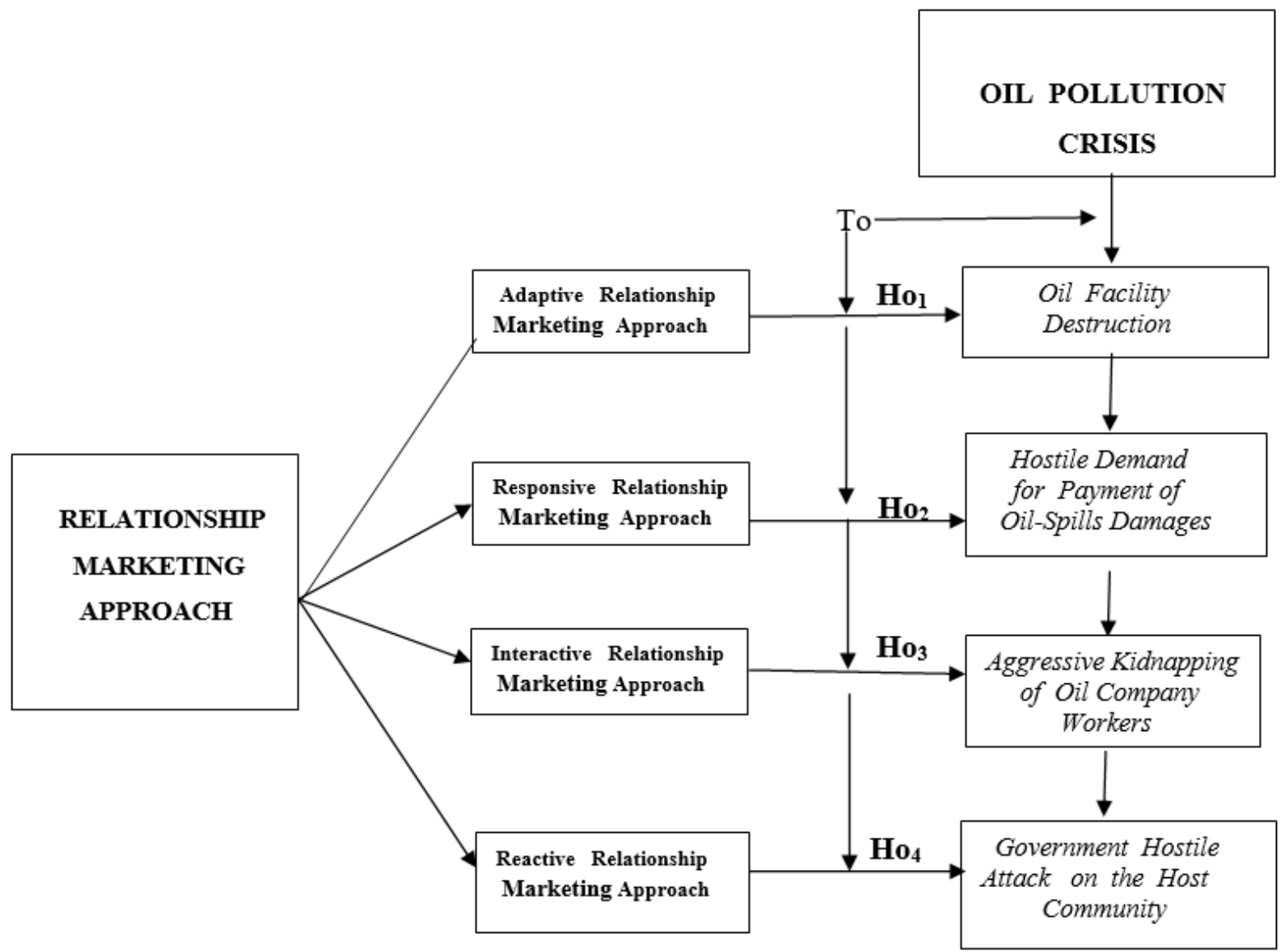

Figure 1: Diagrammatic Analysis of Relationship Marketing Strategies for Customers Retention.

Source: James and Roger (2001), Relationship Marketing Strategies for Customers Retention: Donhan Publishers.

\section{Environmental Oriented Relationship Marketing Perspective of Oil Pollution Crisis}

Analytically, as shown in the diagram above, oil pollution crisis in Niger Delta is traceable to the destruction of the environment, which hinged on the destruction of fruitful agricultural land, safe drinking water, marine lives and quality air has been poisoned with oil spills and gas flaring activities considered unhealthy to human existence. In several instances this situation has led to oil pollution crisis that identified with the destruction of oil facilities, destruction of human life, and kidnapping of oil firms' workers.

Conventionally, the economic perspective of oil pollution crisis is determined based on the extent to which environmental relationship marketing appears to value the purpose of protecting, improving, sustaining, preserving and satisfying the wellbeing of the consumer citizens and the society. Thus, oil pollution and its resultant relationship marketing impact constitutes a model of market failure and oil pollution related economic crisis in Niger Delta. The failure model is used to analyze environmental marketing problems associated with oil 
pollution conflict resulting from the destruction of agricultural production in oil-bearing communities. For this reason, Osabie (2007), argued that poor environmental marketing activities of oil firms has threatened the oil firms' relationship marketing practice by the consumer citizens in the host community.

\section{Adaptive Relationship Marketing Approach and Oil Facility Destruction in Oil Pollution}

\section{Crisis}

Adaptive relationship marketing approach is a strategic marketing technique employed by a firm to adjust or amend its strategic marketing decision to fit into the demand of the consumer citizens (Chukwu, 2008). Similarly, the concern of this study is to examine how oil firms adapt or adjust its relationship marketing decision or approach to meet up the environmental needs and demand of the consumer citizens in oil-bearing community. The use of adaptive relationship marketing approach to reduce or avoid oil facility destruction anchors on the extent to which oil firms' relationship marketing intention to adapt to the emergency demand of the consumer citizens becomes important.

For this and similar reasons, Iba (2013), adds that relationship marketing consideration emphasized in societal marketing concept value, requires that "Firms should identify the needs of the consumers and the society, and adapt best ways of satisfying them, effectively and efficiently than the competitors (Kotler, 2000)". This idea projects the belief that relationship marketing has becomes indispensable to a firm's social activities in an environment where a company operates for the good of the consumers, the society and the company itself.

Without doubt, adaptive relationship marketing practice calls for the end of capitalist oriented age, which contest against the view proposed in Fredman and Wener (1981), holding that, "Profit First and the Wellbeing of the People Later". However, it is obvious that this view does not agree with the right practice of relationship marketing in societal marketing context where a company is allowed to operate for the interest of the consumers and the society in which it operates. The evolutionary development of corporate relationship marketing therefore requires that the classical stage of productive relationship marketing intention should be established by production firms (Chukwu, 2008). In line with this, Osaghae (2007) relates that the multinational oil firms in Niger Delta usually made huge profits from oil pollution and frustrates the social economic wellbeing of the people with the negative consequences in the host communities. Thus, evidence of oil spills traceable to conflicts that resulted in the destruction of oil facilities, killing of innocent citizens, destruction of soldiers, and the destruction of property in the host community has done more harm than good.

This gave rise to the rhetoric question asking, "to what extent does the use of Adaptive Relationship Marketing Approach (ARMA), actually reduced oil facility destruction and payment for oil-spills damages, that leads to oil pollution crisis by the oil firms in Niger Delta? . In an effort to answer this question, Aakol (2009), opined that oil firms in Niger Delta tend not to have been adapting sustainable relationship marketing approach that address oil pollution conflicts base on international standard of operation in the world. According to Iba (2013), oil firms' failure to adapt a proactive marketing relationship in 
dealing with socio-economic crisis generated from oil pollution has not been competitive by its relationship marketing mentality. Ekpu (2010), confirms that the failure of the oil companies to employ adaptive relationship marketing strategy to address the needs and demand of people in Niger Delta has not only caused unwanted harmful health impact, criminal activities, and high mortality rate but considered responsible for grievous negative economic - health consequences on the host community.

In addition, in Bodo community in Ogoni-land of Rivers State, another community conflict raised, showing the general uprising against Shell Petroleum Development Company for its environmental damages. Esedwuo(2008), adds that in another development, the demand for resources control by the Ogonis in 1994 that resulted in the death of four prominent Ogonis sons and nine others including Ken Saro-Wiwa, sum up to justify what could be described as poor relationship marketing practice of the oil firms (Akinbuwa, 2008).

This add meaning to the observation that oil firms seems not to practice effective relationship marketing for not willing to carry out its responsible marketing activity in the host community; even when peaceful protest are raised thereto. This set a stage for not only what the then British Prime Minister, John Major, described as the "Judicial Murder of Ken SaroWiwa and his eight other Ogoni compatriots (Onuoha, 2008). However, the destruction of lives and property in Niger Delta with oil pollution issues was the destructive effort of the oil firms considered working against reliable relationship marketing approach to oil pollution crisis in the oil-bearing community.

A view of the case of the Ogoin 4 and others from the neighboring Ogoni communities in Rivers state was also, internationally justified as evidence of poor relationship marketing impact caused by Shell Petroleum Development Company for being responsible for the death of Ken Saro-Wiwa and others. On a large scale, this incident has stained the reputation of Shell Petroleum Development Company in the international community where sanctions were placed on Nigerian oil; while the resolved decision of the local communities in Ogoni land kept Shell Petroleum Development Company away from its oil fields in all Ogoni Communities since 1993 till date (Onuoha, 2008).

Having known the impact of oil exploration marketing activities based on the relationship marketing approach to economic, health, and environmental wellbeing of the people; Onkvisit and Shaw (2007), asserts that the operational activities of firms are meant to have a sense of concern for the protection of its environment, since only consumer oriented firms employs adaptive relationship marketing attention to environment al issues affecting the wellbeing of the consumers.

In view of this, Osaghae (2007), adds that adaptive relationship marketing approach does not only create public acceptance of the firm in the host society, but also enhance the corporate image and social status of the firm. Therefore, relationship marketing is a effort that drives home the company's consciousness towards its continuous existence as a responsible corporate citizen in the host community. Okoh (2009), puts that oil firms must also adapt to the satisfaction of social needs of the host community by having strong interests in the wellbeing of the oil producing communities. In this vein, relationship marketing responsibility (RMR) of an oil firm will be considered ethically guided towards oil pollution avoidance in a more responsible manner. For this reason, Kotler (2000), described 
relationship marketing as a sustainable marketing strategy trust that improves the value of ethical marketing between the firm and the consumer citizens.

\section{Responsive Relationship Marketing Approach and Demand of Payment for Oil Spills}

\section{Damages in Oil Pollution Crisis}

Responsive relationship marketing is referring to the marketing technique employed by business organizations to provide immediate responsible attention to consumers' complaints, needs and demand that require urgent attention with a sense of concern to satisfy the needs and demand. The responsive relationship marketing activities and socially responsible attitudes of a firm is a function of socially sustainable relationship marketing. Thus, the practice of ensuring responsive relationship marketing is a sustainable marketing that dealt with the proactive marketing effort of attending to consumers' needs and wants in a responsible manner without waiting for aggressive reaction from members of the host community. The application of responsive relationship marketing approach to the demand of payment for oil spills damages is traceable to oil pollution crisis, which anchor on a sense of value. The relationship marketing intention to response to emergency situation and demand of the customer in an effort to avoid conflict is considered responsive. Responsive relationship marketing approach is applicable to the expectation that oil firms should give responsible attention to the demand of the host community without waiting for social crisis before responding to their demand (Onuoha, 2008).

To be more specific, responsive relationship marketing is concern with the exhibition of mutual behaviours in response to urgent issues that required immediate attention. Responsive relationship marketing is conducted in a manner that promotes participatory and defensive response rather than adopting, reactive and retroactive approach to conflict situation (Atatow and Gannon, 1982). To justify this, Osaghae (2007) relates that the practice of responsive relationship marketing and the released of sulfur oxide and nitrogen oxides that forms acid rain, and destroyed the soil fertility is associated with oil-pollution crisis that resulted in the destruction of oil facilities in the community. On this note, Onuoha, 2008), adds that responsive relationship marketing approach presupposes that companies need not have to wait until they are pressurized into actions before responding to important issues; rather, they should anticipate and prevent societal related production problems before they arise

Comparatively, Esedwuo (2008) revealed that, in 1994, Agip and Total Oil Company operating in Egi-clan in Ogbaland also in Rivers state, signed a memorandum of understanding after resolving the violence protects by the host community for better deal where no person secure injury or found death. This was unlike the case of Shell Petroleum Development Company at Umuechem, where over eighty (80) people, including the community chief, were reportedly killed and several houses were completely destroyed (Akinbuwa, 2008). Also, in the year 2000, the youths of Ogbaland community where AGIP, ELF and TOTAL oil companies operate, also demanded for the payment of their Electricity bills from Total, Agip and Elf oil Companies and the issue was resolved in favour of the host community peacefully (Dukun, 2008). Similarly, it is also observed that from the foregoing, only few selected companies has what it takes to settle conflicts with their host communities and stop further violation of the host community' directives that increases the scale of the conflict. This adds meaning to the need for relationship marketing in the oil-bearing community. 
Generally, it is commonly believe that responsive relationship marketing approach is a pragmatic marketing technique employed by business organization to solve the host consumers' problems in the oil-bearing community. Okoh (2009), adds that poor growth of trees, grasses, and other vegetations on land destroyed by oil pollution has been extremely unethical and inhuman in relationship marketing practice. Therefore, responsive relationship marketing practice of the oil firms in the oil-bearing community appears to have been weak for not receiving substantial public acceptance. This relates to the fact that oil pollution crisis in the oil-bearing community is not farfetched from the resultant effect of unethical environmental marketing practice of the oil firms for causing oil pollution that contributed to the fast growing decrease and harmful impact of agricultural production on a large scale (Okoh, 2009). This implies that oil pollution crisis and oil pollution impact on fertile agricultural lands has inflicted economic set back on farmers, fishermen, hunters and timber producers among others.

On a large scale, responsive relationship marketing practice could be considered capable of generating social understanding dissociated from promoting economic damages and destruction of oil facility in the oil-bearing communities in Niger Delta. In line with this, Okoh(2009), explain that responsive relationship marketing as a tactical marketing approach of relating with the customers in response to their needs.. To this end, if a business firm by its relationship marketing activities fails to recognize the relationship between consumers and the ecological systems, the wellbeing of such firm will be threatened by members of the host community(Osaghae, 2007).

Similarly, oil firms' failure to adapt responsive relationship marketing approach has not only caused companies to lose its relationship marketing value in the host community but also discourage mutual understanding and trust between the two parties. This leads to crisis that might take away the company's social rights of operation by the host community. Perreault and Mccarthy (1999), puts that it is better for a firm to think it less expensive to do what is socially right and cost effective at a time, than to pay more-to fix a problem that is led by pressure, and expensive to the firm. Tuyizere (2007) adds that oil-firms are expected to adopt responsive approach rather than reactive approach to violence demand in oil-bearing community.

\section{Interactive Relationship Marketing Approach and Aggressive Kidnapping of Oil}

\section{Company Workers in the Oil Pollution Crisis}

Interactive relationship marketing approach could be considered as the most comprehensive relationship marketing approach that could be adopted by a firm. Interactive relationship marketing approach conveniently enable discussion of feelings, likes and dislikes of customers about a company's product, its production activities and services provided. At this point, interactive relationship marketing approach functions to reduce ill feelings about a firm and improves all-round mutual understanding about the firm's activities, products and service involving customers interest and the society' wellbeing. Tuyizere (2007) adds that interactive relationship marketing approach is the best and the most proactive relationship marketing techniques employed by business organizations to solve complicated and convoluted problems, which worth thousands of dollar. Chukwu(2008),asserts that the use of interactive relationship marketing approach to control aggressive kidnapping of oil company workers is a solution factor traceable to resolve oil pollution crisis. Dukun(2008), justifies 
that relationship marketing intention that focus on the discussion of the host community demand is considered to have engaged in responsible relationship marketing activities of avoiding conflicts. For this reason, Feegalo (2005) opined that business organizations are social solution vanguards that discuss production related activities and how it possible affects on the wellbeing of the society.

Donnely (1984) confirmed that business organization owe its host communities some socially oriented benefits, capable of protecting, sustaining and presrving the social wellbeing of the society in an effort to avoid oil pollution crisis. In this vein, Onuoha (2007), pointed out that interactive relationship marketing approach to conflict situation supersedes adaptive and defensive approach; which might produce temporary or short time benefits to an oil firm.

In the long-run, Okoh (2009), puts that an interactive relationship marketing could be considered a comprehensive approach that bring about a greater and lasting benefits to the firm and its host community that gives the firm the succors to operate. Chukwu (2008), also relates that the truth remains un-arguable, justifying that, oil producing firms that is currently operating in modern society, basically see interactive relationship marketing as a cohesive force that stem oil pollution crisis in Niger Delta.

Eseduwo (2008) asserts that the time gap for oil firms' intervention into a particular demand by the host community has been too long enough to stem social crisis before a demand is met out of plenty. This does not have interactive relationship marketing attributes for crisis prevention. Thus relationship marketing approach of oil firms are guided on what to do, how to do it and when to do it since oil firms in Niger Delta lacks the ability to create positive relationship marketing values with a sense of concern in their host community. Often time, this has resulted in unwanted operational interruption and subsequently social conflict that originate from oil pollution.

For this and other related reasons, Agip, Elf, and Shell Petroleum Development Company recorded some incidents of kidnappings, destruction of oil facilities, and conflicts in their host communities in Niger Delta (MOSOP, 2008). Kotler (2000) posits that quality delivery is every one's job, just as relationship marketing is every person's responsibility to protect the socio-economic values of its environment.

Without doubt, oil pollution that resulted in oil pollution crisis has generated stagnant agricultural productivity, food insecurity, poor crops yields and unproductive harvest; caused by the oil firms has gave birth to unemployment, high poverty expansion rate in rural and urban areas among farmers and distributors of farm yields within the age of 39 years and above (Tuyizere , 2007)). On a large scale, this does not established pragmatic evidence of sustainable relationship marketing in a more responsible manner by oil firms. On this note, the correlation between interactive relationship marketing approach employed by oil firms and their environmental marketing practice has not only resulted in what appears to be social crisis of oil pollution but strong economic threats to natural resources that posed unwanted economic hardship and poverty on the people in Niger Delta.

Having noticed these irregularities, Perreaut and McCarthy (1999) states that marketers ought to give careful attention to harmful environmental issues that result to crisis, for few dishonest or unethical managers has done a great deal of damage to the environment before 
the consumer citizens takes the necessary steps to stop them. To justify this truth, Dukun (2008) adds that the limitation of the available farming space with pipelines crisscrossing the farmlands, streams, creeks and villages in Niger Delta could not give farmers access to farm on their lands and fishermen access to fish in their rivers, thereby generating untold economic war, economic hardship and social crisis in the host communities. Utukepo (2011) confirm that the effective relationship marketing approach of the oil-firms does not have positive bearing with issues of oil pollution in Niger Delta where people groan under the perennial destruction of their property and the ecosystem by oil spillage and gas flaring activities that keep resulting in oil pollution related crisis.

\section{Reactive Relationship Marketing Approach and Government Hostile Attack on the Host Communities in Oil Pollution Crisis}

Reactive relationship marketing approach is a type of relationship marketing techniques adopted by a firm used in responding to an urgent or emergency action that calls for prevention measures in avoidance harmful result (Okoh, 2009). Without doubt, reactive relationship marketing approach to oil pollution crisis is a responsive action, carried out with the aim to prevent, calm or control the effect of an unwanted action (Tuyizere,2007). On this note, Chukwu (2008) adds that a business organization must not only consider for the provision of goods and services to the society for profit but must also account for the protection and sustainability of the ecological and environmental wellbeing of the host community, but to contribute to solving the society's social problems in a bid to prevent conflicts. The application of reactive relationship marketing approach to government hostile attack on the host community is traceable to oil pollution crisis that anchor on the to react to urgent, immediate or emergency situation leading to the demand of the host community in an effort to avoid conflict.

Reactive relationship marketing approach is demonstrated in a form of behavior that reacted to a current prevailing action that is not in terms with the social norms, values, ethics and expectations of the society (Ukaogo, 2007). This implies that, when an oil firm reacted to sudden demand of the host community, a preventive measure is taken to control the negative impact of the action immediately. Such relationship marketing reaction might not be societal marketing oriented while the action by the host communities might not be ethically guided to agree with the social norms and values of the society. Thus, conflict is expected to take place. This calls for the rhetoric question, asking whether the use of Reactive Relationship Marketing Approach (RRMA), to oil facility destruction has positively reduced oil pollution crisis by the oil firms in Niger Delta. In an effort to answer this question, Okoh (2009) adds that oil firms has not ceased causing oil pollution crisis since 1958 precisely, when Shell BP started its operation in Ogoni land; where oil spills has caused dangerous toxic substances on the farm-lands and water bodies containing hydrocarbons, acidic chemicals, inorganic metals, such as mercury or arsenic flammable solvents, pesticides, herbicides phenols and explosive among others to destroy the green land value. Gabriel (2017) equally observed that reactive relationship marketing approach employed by the oil firms has resulted in oil pollution crisis that connects issues of agricultural land limitation and frustration of marine source of livelihood in oil-bearing communities. The degree of relationship between oil pollution crisis and reactive relationship marketing approach of the oil firms, confirms that there is an existing weak relationship marketing between the oil-bearing communities in Niger Delta and the oil firms that render the land unproductive and limit the agricultural and marine source livelihood (Tuyizere, 2007). This implies that the value of relationship 
marketing practice adopted by the oil firms has been soured since the oil firms' environmental marketing practice in Niger Delta has resulted in social crisis associated with unprecedented poverty, unemployment, infrastructural decay, moral decadence and fastgrowing criminal activities in the oil-bearing communities (Okoh, 2009).

To this end, the truth about whether oil firms' reactive relationship marketing was useful to the host community remains questionable following the seeming endless oil pollution activities of oil firms. Hence, the impact of the exploration activities that promotes environmental degradation, socio-economic frustration, has posed potential threats to the people main source of livelihood considered unsustainable and capable of causing oil facility destruction, oil and pollution crisis that resulted in government hostile attack by soldiers .

Similarly, reactive relationship marketing approach of the oil firms on the economic demand of the oil bearing communities was not only unethically guided but appears provocative when considering the level of environmental destruction and its related mortality rate in the host communities. No wonder Ekpu (2010) observes that we witnessed the slow poisoning of the waters of this country and the destruction of vegetations and agricultural lands by oil spills that occur during petroleum operations without proactive marketing relationship approach to stem the deadly effects. In view of this, Williams (2000), asserts that even the welfare of non-humans are intrinsically valuable and morally assessed for protection with great respect to preserve and sustain their natural environment which the oil firms over look in their oil production activities.

In reality, the marketing activity of exploring the black gold had brought sorrows and tears to the land of Niger Delta, where their dreams died an unnatural death, and their agricultural sustainable source destroyed goes comatose, while economic hardship, poverty and land limitation has becomes their worst portion; than what is even existing in the remotest part of Koma region, a primitive society in Adamawa state of Nigeria (Aakol, 2009). On a large scale, this calls for a natural question, asking: "To what extent does the use of reactive relationship marketing approach to oil pollution, positively reduced the trend of oil pollution crisis by oil firms operating in Niger Delta?" In response, Ekpu (2010) adds that oil pollution has been a natural phenomenon in the scheme of oil exploration in Nigeria where social related crisis becomes obvious as the outcome of the companies' relationship marketing approach. Udu (2007) affirms that Nigeria government has not ceased to threatened the host community's reactive approach against incessant oil pollution in Niger Delta. Schiffman and Kanuk (2009), adds that favorable attitudes of a company, encourage effective product positioning and positive image marketing that stimulate discrimination and proper identification of a company's value from others production firms for retention of long-term memory that influence consumers' repeat response behavior.

Udu(2007), asserts that production oriented marketers are often criticized for their unethical marketing activities and relationship marketing for failure to ensure quality delivery in the protection, improvement, sustainability and preservation of their environment. Kotler (2000) emphasized that "It is more important for business organizations to do what is strategically right than what is immediately profitable; for it is no longer enough to satisfy customers, you must delight them". Also, Frank Hungal, an American executive, states also that "My firm serves the target market because the customers give the firm the opportunity to serve; and the firm cannot survive or exist without them (Schiffman and Kanuk , 2009)". This implies that oil firms cannot operate in crisis environment and cannot serve the target market where the 
host community does not offer the firm the opportunity to operate and serve; otherwise their activities will be criticized for their irresponsible and unethical marketing activities.

\section{EMPIRICAL REVIEW}

The empirical review of this study establishes relationship marketing practice for the avoidance oil pollution that hinged on the economic wellbeing of the oil-producing communities.

Odu (2007) investigated the "Impact of Oil Pollution Crisis on Agricultural Production in Cross Rivers State with focus on Shell Petroleum Development Company”. Data analyzed with chi-squire statistics from a sample size of 300 respondents drawn from five oilproducing communities revealed with critical evidence that "Oil Pollution Crisis does not positively impact on Agricultural Production by SPDC in Cross Rivers State". This means that Shell Petroleum Development Company frustrated agricultural production and other socio-economic developments in the oil-producing communities". It was therefore suggested that Shell Petroleum Development Company should improve on its oil production activities by avoiding oil pollutions and boost agricultural production alongside other socio-economic development in the oil-producing communities. The relevance of this study anchors on its relationship with Oil Pollution Crisis on Agricultural Production. The implication of this study is that oil firms might experience social crisis that may cause economic failure in Niger Delta and the country at large if; mutual marketing relationship between the firms and the host communities is not strengthen with more responsible approach to boost agricultural production.

Sauka and Oshita (2007) investigated AGIP Company's Oil Exploration Crisis and Economic Poverty in Rivers State. The study aims at examining the extent of oil exploration has reduced economic poverty in the oil-producing communities. A sample of 320 respondents was used; and data generated were analyzed with the use of chi-squre statistics techniques. Results obtained revealed that there is significant relationship between AGIP Company's Oil Exploration Crisis and Economic Poverty in Rivers State. Economic poverty at high level alongside its oil pollution was in place. It was therefore, recommended that more proactive measures should be adopted to ensure more drastic reduction in the level of poverty caused by oil pollution in the host communities. The relevance of this study anchors on its relationship with Oil Exploration Crisis and Economic Poverty. The implication of this study is that oil firms might experience social crisis that may cause economic failure in Rivers State, Niger Delta and the country at large if; mutual marketing relationship between the oil firms and the host communities is not strengthen with more responsible approach to reduced economic poverty.

Koateh and Menele (2007), in a study of "ELF Company" Oil Exploration and Environmental Degradation Crisis in Bayelsa State", a 22 questions construct were served on 260 respondents in 12 local oil communities in Bayelsa State. Data analyzed using t-test statistics revealed that "There is no significant relationship between "ELF Company' Oil Exploration and the Environmental Degradation Crisis in Bayelsa State". The relevance of this study anchors on its relationship with Oil Exploration and Environmental Degradation Crisis in Bayelsa State. The implication of this finding is that oil firms might experience 
social crisis that may cause economic failure in Bayelsa State, Niger Delta and the country at large if; mutual marketing relationship between the oil firms and the host communities is not strengthen with more responsible approach to reduced environmental degradation crisis in the state.

Using Shell Petroleum Development Company and ELF Oil Company in Niger Delta, Amadi and Nwomaji (2008) studied "the Effects of Oil Exploration Crisis on the Economic Development of Oil-Producing Communities in Akwa-Ibom, Rivers and Delta State" with a 26 count item questions on a survey instrument. Data obtained and critically analyzed with the use of "Analysis of Variance (ANOVA), statistical techniques reveals that, "There is significant effect of oil exploration crisis on the economic development in oil-producing communities in Akwa-Ibom, Rivers and Delta State". The relevance of this study anchors on its relationship with Shell Petroleum Development Company and ELF Oil Company in Niger Delta on the Effects of Oil Exploration Crisis on the Economic Development of OilProducing Communities in Akwa-Ibom, Rivers and Delta State" . The implication of this study is that oil firms might experience social crisis that may cause economic failure in Akwa-Ibom, Rivers and Delta State, Niger Delta and the country at large if; mutual marketing relationship between the oil firms and the host communities is not strengthen with more responsible approach to reduced the effects of oil exploration crisis on the economic development of oil-producing communities.

Hegbataama (2011) investigated the "Impact of SDPC Relationship Marketing on agricultural production of Safe Foodstuffs in the oil-bearing communities in Delta State", using 32 questions on a sample size of 300 literates' farmers in Delta state. Data analyzed with the use of Gamma test of relationship revealed that "there is evidence of negative relationship between Shell Petroleum Development Company's relationship marketing and the agricultural production of safe foodstuffs in the oil-bearing communities of the State". The relevance of this study anchors on its relationship with SDPC Relationship Marketing on agricultural production of Safe Foodstuffs in the oil-bearing communities in Delta State". The implication of this study is that oil firms might experience social crisis that may cause economic failure in Delta State, if; mutual marketing relationship between the oil firms and the host communities is not strengthen with more responsible approach to boost Relationship Marketing on agricultural production of Safe Foodstuffs in the oil-bearing communities in Delta State".

Benconi (2010) in a study of “Agip Oil Company's Environmental Responsibility and Relationship Marketing in Niger Delta"; used chi-square statistical technique to analyze data gathered from 320 respondents. The study reveals that, "the environmental concern of the company was harmful and irresponsible to the socio-economic interests and environmental wellbeing of the oil-bearing communities". It was therefore, advisable that the company should build in more responsible interest and attitudes in handling environmental problems. The relevance of this study anchors in its relationship with environmental responsibility and relationship marketing in Niger Delta. The implication of this study on the current study is that Agip oil company's environmental responsibility in Niger Delta is expected to be harmless in its effort to avoid the harmful impact of oil spillage on the host communities by been responsible; and if this is not done, oil firms might experience social crisis that may cause economic failure in Niger Delta and the country at large if; mutual marketing relationship between the firms and the host communities is not strengthen with more responsible approach. 
In spite of the contributions of the empirical review of this study, it is observed that the study have some empirical gaps indicated at the end of the theoretical framework.

\section{THEORETICAL FRAMEWORK}

In this study, the ecological system theory is adopted.

\section{Ecological Environmental System Theory}

This study employed ecological environmental system theory to explain the implication of ecological ethics on the ecological environmental system as justified in the ethical marketing perspective of relationship marketing practice on oil pollution crisis of the oil producing firms. In harmony with this, relationship marketing practice of oil firms seeks to provide mutual relationship between the consumer citizens in the host community and the oil firm for the purpose of sustaining the existence and wellbeing of both parties. The relationship marketing effort adopted to satisfy the consumer citizens, ensure environmental protection and the long-term interests of the oil-bearing community alongside the sustainability of the ecosystem. Socio-economic environmental need of the consumer citizens and the society's wellbeing is considered by this theory as a positive relationship marketing driver instituted to avoid oil pollution crisis. In line with this reality, Wriote Anderson propounded the ecological environmental system theory in 1992, as cited by Miller, Moham Recido in 2007. The theory states that "the ecological environment is an hybrid of complex whole, made up of sub-components, consisting of interrelated and inter-dependent set of organisms, plants, the environment, driven by ethical based factor which functions in common for the preservation, improvement, sustainability, protection and satisfaction of the wellbeing of the earth inhabitants (living and non-living things); and the society" (Miller, 2007).

To justify this, the theory emphasizes on the assumptions that "the successful existence of the organisms, plants and other inhabitants in the environment, are considered to have their lives protected, sustained and guided by moral and ethical factors. The protection, improvement and sustainability of these organisms, plants and other inhabitants in the environment become the functional value of a sustainable environmental relationship marketing that prevents oil pollution crisis within the context of a better ecological system. The ecological environmental system theory is therefore driven by the intention to ensure proactive environmental relationship marketing guide with the view to enhance reliable sustainability, improvement, protection and preservation of the consumers and the society's wellbeing in a natural environment. Thus, the essence of the theory, guiding against oil pollution is a relationship marketing effort to enhance the wellbeing and long term interest of the consumer citizens and the society.

The theorist further maintain that the ecological environment consist of a set of interrelated and interdependent sub-systems that function together for the achievement of a common goal for their survival. This attempts to explain that the various parts that make up the ecological system like the water, land, air, fish, aquatic organisms, animals, plants and waste products, including others are interrelated, and that the activities of one of its part affects the survival of each part depends upon the survival of the other parts of the system; which its operational activities and existence is sustained by the ecosystem as guided by environmental marketing 
ethical tenets. This forms a coherent function of the system that leads to the achievement of a set of goals for the wellbeing of man and the society.

On this note, oil pollution is viewed as crisis oriented variable that posed unwanted negative constraint on the economic based ecological system of the oil-bearing community. This oil pollution is known to exist with the hydrocarbon petroleum substance that poisons the ecological system and needed to be guided by natural and moral ethics. Thus, the violation of ecological environmental system theory by the oil firms leading to oil pollution crisis is poisonous to ethical perspective of the theory. Therefore, the ecological, environmental, and ethical content of the theory seeks to project the conventional reality of sustainable relationship marketing and its approach to oil pollution crisis in a safer and responsible manner. Thus, the ecological environmental system theory is used to describe the relationship between the ecosystem and the relationship marketing activities of the oil firms in an effort to sustain the wellbeing of the environment and its socio-economic variables; which the healthy condition of the flora and fauna is not excluded as a supportive means of the people's natural source of livelihood.

In spite of the contributions of the empirical review of this study, it is observed that none of the empirical reviews shows evidence of an existing study which specifically examined "Relationship marketing practice and oil pollution issues in oil-bearing communities in Niger Delta". Also, the objectives of this study were not examined in any of the previous studies". Indeed, the present research background, problem and scope of this study are entirely different from the review in realted studies. These are existing empirical gaps not covered in the review of previous related studies of this work. Consequently, this evidence gave birth to the need that forms a research thrust of this study to find out whether the relationship marketing practice of the oil firms: Shell BP, Agip Oil Company, and Elf Oil Company has significantly improved the wellbeing of the oil-bearing communities from the hazards of oilpollution in Niger Delta. Thus, the study seeks to close the empirical gap not covered.

Theatrically, the theory applied in the study was silence about how the business organizations can use ecological environmental system theory to reduce the trend of oil pollution crisis in Niger Delta; which is a theoretical gap that this study seeks to close.

In line with this, the contributions drawn from the review of related literature were based on mere observations and empirical review of related studies that have no direct justifiable conclusion of living evidence to the research questions and hypotheses of this study. Hence, the contributions of the literature review were not enough as required in a survey-oriented research. For this reason, it was observed that there is an established gap, which was not covered for lacking justifiable merits of a research survey reliability in which responses from the natives of the affected oil-bearing communities were not tested to confirm the practical validity of the reviewed literature. In order to close this gap, the need for further methods and procedures of findings, calls for scientific test of confirmation with the right tools to arrive at a more cohesive and reliable conclusion of the finding. 


\section{METHODOLOGY}

\section{Research Design}

The descriptive survey method of co-relational research design was adopted in this study to provide detail investigation of the procedure used to establish the relationship between the impact of societal marketing principles and the environmental marketing activities of the oil firms in Niger Delta. In line with this, a set of questionnaire, containing 15 items questions was structured and administered on respondents drawn from Niger. A modified 4-point Likert scale format cited in (Uzuaguru, 2002), was employed in the design of questionnaire used to generate data needed for statistical computation. Both descriptive and inferential statistics involving the mean score test, simple percentage test, and Pearson Product Moment Correlation Co-efficient statistical method was used for the analysis of data obtain for the study. The study was carried out in the oil-bearing communities of Niger Delta, located in the southern part of Nigeria. The population of the study is 37,965,391 people consisting of males and females, conveniently drawn from eight Niger Delta States: Akwa-Ibom State $(5,482,177)$, Bayelsa State $(2,277,961)$, Delta State $(5,663,362)$, Rivers State $(7,303,924)$, and Cross Rivers State $(3,866,269)$, Edo State(4,235,595), Imo State $(5,408,756)$, and Abia State(3,727,347), popularly known as the political Niger Delta states (See National Population Commission of Nigeria-Web). The population was determined, using Taro Yamene's sample size techniques at 0.5 percent level of significant cited in Ani (2012).

\section{Population of the Study}

The population of this study is drawn 37,965,391 residents of Niger Delta comprising Rivers State(12.5\%), Bayelsa State(12.5\%), Akwa-Ibom State(2.5\%), Delta State(12.5\%), Edo State(12.5\%), Imo State (12.5\%), and Abia State(12.5\%), and Cross River State(12.5\%) out of nine States (See National Population Commission of Nigeria-Web).

\section{Determination of Sample Size}

In order to determine a valid sample size for this study, Taro Yamane's finite population sample size formula cited in Ani (2012) and Uzuaguru (2000) was adopted. The formula is given as:

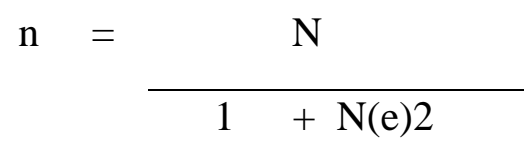

Where:

$\mathrm{n}=$ unknown sample size to be determined

$\mathrm{N}=$ total population of the study $(17,087,503)$

$\mathrm{e}=$ the level of significance at 5\% (0.05)

$1=$ constant 


\begin{tabular}{|c|c|c|c|c|}
\hline Thus: & $\mathrm{n}$ & $37,965,391$ & $=$ & $37,965,391$ \\
\hline
\end{tabular}

The purposive sampling technique was adopted in the study with equal percentage representation to ensure fair distribution of the questionnaire to the sample population of 400 respondents drawn from Rivers State(12.5\%), Bayelsa State(12.5\%), Akwa-Ibom State $(2.5 \%)$, Delta State(12.5\%), Edo State(12.5\%), Imo State (12.5\%), and Abia State $(12.5 \%)$, and Cross River State(12.5\%). The eight states chosen out of nine was considered a convenient researchable representation of the study locations. The sample frame is presented below.

Table 2: $\quad$ Sample Frame for Questionnaire Distribution

\begin{tabular}{|l|cc|c|c|cc|ccc|}
\hline & \multicolumn{8}{|c|}{ Distribution of Sample Size } \\
\cline { 2 - 9 } \\
$\begin{array}{l}\text { Sample } \\
\begin{array}{l}\text { Population } \\
\text { Size }\end{array}\end{array}$ & Abia & Rivers & & Akwa- & Delta & Imo & Cross River & Edo & Total \% \\
& & $12.5 \%$ & Bayelsa & Ibomt & $12.5 \%$ & & $12.5 \%$ & $12.5 \%$ & $100 \%$ \\
\hline $\mathbf{4 0 0}=$ & 50 & 50 & 50 & 50 & 50 & 50 & 50 & 50 & 400 \\
\hline
\end{tabular}

\section{Nature and Source of Data}

The primary source of data was mainly employed for this study. However, the secondary data source used was merely supportive to elicit secondary information.

\section{Method of Data Collection}

The primary source of data was used to elicit relevant responses from respondents in this study. A set of structured questionnaire was administered to four hundred (400) respondents via five research assistants and out of the four hundred (400) successful questionnaires administered, only three hundred and eighty three (383) copies being $96 \%$ of the questionnaire was returned successfully, while eight (17) copies being $4 \%$ was not returned The distribution sample frame from respondents is shown below.

Table 3: $\quad$ Number of Questionnaire Distributed and Returned

\begin{tabular}{|l|l|l|c|}
\hline $\begin{array}{l}\text { Categories of } \\
\text { Respondents }\end{array}$ & $\begin{array}{l}\text { Number } \\
\text { Distributed }\end{array}$ & $\begin{array}{l}\text { Number } \\
\text { Returned }\end{array}$ & $\begin{array}{c}\text { Number } \\
\text { Not Returned }\end{array}$ \\
\hline Males & $162(40 \%)$ & $148(37 \%)$ & $14(3 \%)$ \\
\hline Females & $238(60 \%)$ & $220(55 \%)$ & $18(5 \%)$ \\
\hline Total & $\mathbf{4 0 0}(100 \%)$ & $\mathbf{3 6 8}(\mathbf{9 2 \%})$ & $\mathbf{3 2}(\mathbf{8 \%})$ \\
\hline
\end{tabular}




\section{Administration of Instrument}

A set of questionnaire containing 20 item questions were structured and administered to elicit relevant responses from the 400 respondents; out of which only three hundred and eighty three (383) copies being $96 \%$ of the questionnaire was returned successfully, while eight (17) copies being $4 \%$ was not returned with the aid of five research assistants used for study. The researcher used only five research assistants to administer and retrieved questionnaires. The variables investigated in this study were operationalized, using relationship marketing approach to determine if there is a significant relationship between the relationship marketing approach of oil firms and oil pollution crisis in Niger Delta. The sub-operational variables, such as adaptive relationship marketing, responsive relationship marketing, interactive relationship marketing and reactive relationship marketing were measured to examine the extent to which oil pollution crisis of the oil firms has been reduced.

\section{Validation of the Research Instrument}

The validation of the research instrument was confirmed by three research experts from university of Port Harcourt (two from marketing department and one from the department of measurement and evaluation), whose observations, modifications, views, suggestions and recommendations of the instrument confirmed its face and content validities. Significantly, the vetting, modification and validation of the instrument done by these 3 experts, jointly affirmed the instrument as one having the required validity. Cohen and Swerdlick (2010) assert that 'if experts who assess the instrument do not perceive its test as valid, the validity of the instrument is questionable'. In line with this, Gay, (2010), confirms also that the validity coefficient of a valid instrument is determined based on the reliability of the instrument validity to measure what is intended to be measured; and the ability of the validity to yield scores which its difference reflect also in the actual measured variables. Thus, justifying the reality that a reliable validity coefficient of a test instrument, which confirms that a perfect validity is a perfect reliability (Grinnell, 2011). On this note, the coefficient of ' $\mathrm{R}$ ' being .83 , indicates that "reliable validity coefficient of the test instrument was obtained".

\section{Reliability of the Research Instrument}

The reliability of the instrument used with a test of 185 copies was administered. Traditionally, reliability of an instrument is a matter of whether a particular instrument applied repeatedly to the same object yields the same result each time tested. The researcher adopted the test-retest technique based on which questionnaires were administered twice (first and second test) to the same group of respondents within a given time interval of 3 weeks. With the aid of the scores obtained, the test re-test method of reliability was adopted, using Spearman's Rank Order Correlation Coefficient employed to determine how consistent and stable the scores were. When the internal consistency of the instrument was determined, the result of reliability co-efficient of the instrument obtained was ' $R$ ' $=.83$. This indicates considerable evident of reliability in the relationship between the first and second test of reliability of the instrument. Indeed, the test-retest reliability co-efficient of stability of the test result was established. A modified 4-point interval measurement approach on Likert scale format cited in (Uzuaguru, 2002), was used in the questionnaire design to generate data needed for computation. Babbie (2007), confirms that "reliability" is the quality of measured 
results, which suggests that the same data- that has been collected each time in repeated observations of the same phenomenon are reliably the same.

\section{Method of Data Analysis}

The analysis of data obtained was done using the mean score statistics. The interpretation of the mean test result was done, using the following benchmarks: $1.00-1.99(10 \%-29 \%)$ stands for very low extent, 2.00 - 2.99(30\%-49\%) shows low extent, $3.99-3.99(50 \%-69 \%)$ stands for moderate extent, and 4.00 and above (70\%-100\%) indicates high extent were employed in the study. The hypotheses of the study were tested, using Pearson's Product Moment Correlation Co-efficient, which the formula is shown as follows:

$$
\mathrm{r}=
$$

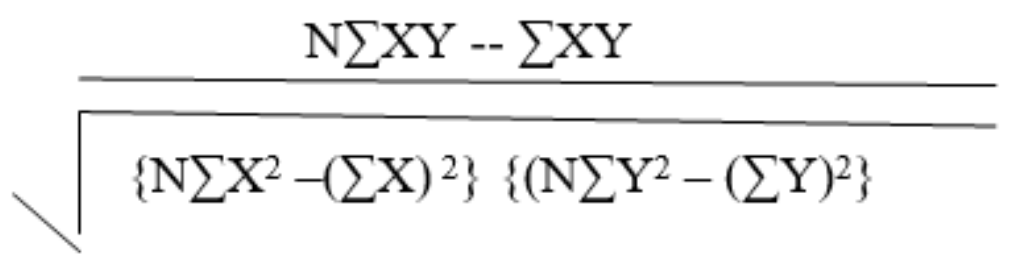

Where:

$$
\begin{aligned}
& \mathrm{X}=\text { the scores on first variable } \\
& \mathrm{Y}=\text { the scores on the second variable } \\
& \mathrm{n} \quad=\text { the total number of cases }
\end{aligned}
$$

To test for its significance, we use:

$$
\operatorname{tr}=\sqrt{\frac{1-r^{2}}{n-2}}
$$

\section{Decision Criteria:}

Where t-computed < t- critical value, accept Ho, and reject Ha.

\section{RESULTS AND DISCUSSION OF FINDINGS}

This is concern with data presentation, analysis, results and discussion of findings for interpretation. It deals with descriptive statistics that analyze answers to research questions and inferential statistics that analyze the hypotheses of the study.

\section{Data Presentation}

\section{Questionnaire Distribution and Collection from Respondents}

The number of questionnaires distributed and collected from the respondents with the help of 5 research assistants was considered useful for the study as carefully, presented below. 
Table 4: Total Number of Questionnaire Distributed and Returned

\begin{tabular}{|c|l|l|l|}
\hline $\begin{array}{c}\text { Categories } \\
\text { Respondents }\end{array}$ & of & Number & Number \\
Returned & $\begin{array}{l}\text { Number } \\
\text { Returned }\end{array}$ \\
\hline Males & $162(40 \%)$ & $148(37 \%)$ & $14(3 \%)$ \\
\hline Females & $238(60 \%)$ & $235(59 \%)$ & $3(1 \%)$ \\
\hline Total & $\mathbf{4 0 0 ( 1 0 0 \% )}$ & $\mathbf{3 8 3 ( 9 6 \% )}$ & $\mathbf{1 7}(\mathbf{4 \%})$ \\
\hline
\end{tabular}

Source: Field Survey Data 2021

The table above shows how the 400 questionnaires distributed were returned at $96 \%$ distribution rate to 383 respondents, while 17 copies at $4 \%$ were not returned from the male and female respondents served.

\section{Social Demographic Data of Respondents.}

Social demographic information concerning respondents used for this study is presented on table 5 and 6 below.

Table 5: Distributions of Respondents by Age

\begin{tabular}{|c|c|}
\hline $\begin{array}{l}\text { Age Bracket } \\
\text { Percentage }\end{array}$ & Frequency \\
\hline $18-25$ & 63 \\
\hline $26-35$ & 132 \\
\hline $36-45$ & 120 \\
\hline $46-55$ & 85 \\
\hline $100 \%$ & 400 \\
\hline
\end{tabular}

Source: Survey Data 2021

The table above shows the analysis of the various age brackets within the age bracket of 18$25,26-35,36-45,36-45$ and $46-55$; which have the frequency distribution values of $63(16 \%), 132(33 \%), 1120(30 \%)$ and $85(21 \%)$ respectively; in confirmation of 400 copies of questionnaire administered at $100 \%$ distribution rate to the respondents. 


\section{Distribution of Questionnaire by Gender Respondents' Categories}

The analysis of how copies of questionnaires were distributed to select the different categories of respondents used for the study.

Table 6: Distribution of Questionnaire by Gender to Selected Categories of Respondents

\begin{tabular}{|c|c|c|c|c|c|}
\hline $\begin{array}{l}\text { Respondents } \\
\text { Categories }\end{array}$ & Traditional Rulers & Women Leaders & Youth Leaders & Church Leader & Total \\
\hline Males & $66(16.5 \%)$ & $0(0 \%)$ & $67(16.7 \%)$ & $67(16.7 \%)$ & $200(50 \%)$ \\
\hline Female & $0(0 \%)$ & $66(16.5 \%)$ & $67(16.7 \%)$ & $67(16.7 \%)$ & $200(50 \%)$ \\
\hline Total & $80(20 \%)$ & $80(20 \%)$ & $80(20 \%)$ & $80(20 \%)$ & $400(100 \%)$ \\
\hline
\end{tabular}

Source: Field Survey Data 2021

The table above shows how the questionnaires were distributed to male and female respondents in the categories of gender for traditional rulers 66(16.5\%), women leaders $66(16.5 \%)$, youth leaders $67(16.7 \%)$, and church leaders $67(16.7 \%)$ respectively; to confirm a total distribution of $400(100 \%)$ questionnaires distributed.

\section{RESULTS}

Table 7: To what extent does the oil firms' "Adaptive Relationship Marketing Approach" to oil pollution crisis, reduced the trend of oil facility destruction in Niger Delta? $(\mathbf{n}=383)$

\begin{tabular}{|l|l|l|l|l|l|l|l|l|}
\hline & & SA & A & D & SD & $\begin{array}{l}\text { TOT } \\
\text { AL }\end{array}$ & $\begin{array}{l}\text { X } \\
\text { DE } \\
\text { C }\end{array}$ \\
\hline 1 & $\begin{array}{l}\text { To what extent does the use of } \\
\text { adaptive relationship approach } \\
\text { reduced oil pollution crisis in Niger } \\
\text { Delta? }\end{array}$ & $\begin{array}{l}115 \\
(460)\end{array}$ & $\begin{array}{l}95 \\
(285)\end{array}$ & $\begin{array}{l}43 \\
(86)\end{array}$ & $\begin{array}{l}130 \\
(130)\end{array}$ & $\begin{array}{l}961 / 3 \\
83\end{array}$ & 2.5 & $+\mathrm{V}$ \\
\hline 2 & $\begin{array}{l}\text { To a large extent, adaptive } \\
\text { relationship marketing approach has } \\
\text { frustrated oil pollution crisis } \\
\text { management in Niger Delta }\end{array}$ & $\begin{array}{l}87 \\
(348)\end{array}$ & $\begin{array}{l}109 \\
(327)\end{array}$ & $\begin{array}{c}103 \\
(206)\end{array}$ & $\begin{array}{l}84 \\
(84)\end{array}$ & $\begin{array}{l}965 / 3 \\
83\end{array}$ & 2.5 & $+\mathrm{V}$ \\
\hline 3 & $\begin{array}{l}\text { Adaptive relationship marketing } \\
\text { approach has been extensively useful } \\
\text { in the control of oil pollution crisis }\end{array}$ & $(64)$ & $\begin{array}{l}206 \\
(618)\end{array}$ & $\begin{array}{c}63 \\
(126)\end{array}$ & $\begin{array}{l}98 \\
(98)\end{array}$ & $\begin{array}{l}906 / 3 \\
83\end{array}$ & 2.3 & $-\mathrm{V}$ \\
\hline 4 & $\begin{array}{l}\text { The practice of adopting to } \\
\text { relationship marketing approach has } \\
\text { been extremely weak to reduce oil } \\
\text { pollution crisis. }\end{array}$ & $(420)$ & $\begin{array}{l}105 \\
(159)\end{array}$ & $\begin{array}{l}178 \\
(356)\end{array}$ & $\begin{array}{l}47 \\
(47)\end{array}$ & $\begin{array}{l}982 / 3 \\
83\end{array}$ & 2.5 & $+\mathrm{V}$ \\
\hline
\end{tabular}




\begin{tabular}{|l|l|l|l|l|l|l|l|c|}
\hline 5 & $\begin{array}{l}\text { Interactive relationship marketing } \\
\text { approach has to a large extent helps } \\
\text { to enhance oil spills maintenance. }\end{array}$ & $\begin{array}{l}13 \\
(552)\end{array}$ & $\begin{array}{l}35 \\
(105)\end{array}$ & $\begin{array}{c}90 \\
(180)\end{array}$ & $\begin{array}{l}120 \\
(120)\end{array}$ & $\begin{array}{l}957 / 3 \\
83\end{array}$ & 2.4 & $-\mathrm{V}$ \\
\hline & GRAND MEAN & & & $\begin{array}{l}\mathbf{2 . 4} \\
\mathbf{4}\end{array}$ & $-\mathrm{V}$ \\
\hline
\end{tabular}

Source: Field Survey Data 2021

Based on the benchmark used in the study, the response obtained as the answer to research question 1, on table 7 above, shows the total grand mean result of 2.44; which descriptively, indicates that "Oil firms" "Adaptive Relationship Marketing Approach" to oil pollution crisis, has to a low extent reduced the trend of oil facility destruction in Niger Delta".

Table 8: To what extent does oil firms' "Interactive Relationship Marketing Approach" to oil pollution crisis reduced the trend of kidnapping oil company workers in Niger Delta? $(\mathbf{n}=383)$

\begin{tabular}{|c|c|c|c|c|c|c|c|c|}
\hline & & SA & $\mathrm{A}$ & $\mathrm{D}$ & SD & TOTAL & $\mathrm{X}$ & DEC \\
\hline 1 & $\begin{array}{l}\text { To what extent does the use of } \\
\text { interactive relationship } \\
\text { marketing approach improved } \\
\text { oil pollution crisis } \\
\text { management?. }\end{array}$ & $\begin{array}{l}115 \\
(460)\end{array}$ & $\begin{array}{l}95 \\
(285)\end{array}$ & $\begin{array}{l}43 \\
(86)\end{array}$ & $\begin{array}{l}130 \\
(130)\end{array}$ & $961 / 383$ & 2.5 & $+\mathrm{V}$ \\
\hline 2 & $\begin{array}{l}\text { To a large extent, interactive } \\
\text { relationship marketing } \\
\text { approach } \\
\text { has fruitfully reduced oil } \\
\text { pollution crisis in Niger Delta }\end{array}$ & $\begin{array}{l}87 \\
(348)\end{array}$ & $\begin{array}{l}109 \\
(327)\end{array}$ & $\begin{array}{l}103 \\
(206)\end{array}$ & $\begin{array}{l}84 \\
(84)\end{array}$ & $965 / 383$ & 2.5 & $+\mathrm{V}$ \\
\hline 3 & $\begin{array}{l}\text { Interactive relationship } \\
\text { marketing approach has been } \\
\text { extensively useful in the } \\
\text { improvement of oil pollution } \\
\text { crisis regulation. }\end{array}$ & $\begin{array}{l}16 \\
(64)\end{array}$ & $\begin{array}{l}206 \\
(618)\end{array}$ & $\begin{array}{l}63 \\
(126)\end{array}$ & $\begin{array}{l}98 \\
(98)\end{array}$ & $906 / 383$ & 2.3 & $-\mathrm{V}$ \\
\hline 4 & $\begin{array}{l}\text { Interactive relationship } \\
\text { marketing approach through } \\
\text { marketing orientation has } \\
\text { extremely enhanced oil } \\
\text { pollution } \\
\text { reduction in Niger Delta. }\end{array}$ & $\begin{array}{l}105 \\
(420)\end{array}$ & $\begin{array}{l}53 \\
(159)\end{array}$ & $\begin{array}{l}178 \\
(356)\end{array}$ & $\begin{array}{l}47 \\
(47)\end{array}$ & $982 / 383$ & 2.5 & $+\mathrm{V}$ \\
\hline 5 & $\begin{array}{l}\text { Interactive relationship } \\
\text { marketing approach of oil } \\
\text { firms has to a large extent } \\
\text { helps to promote oil pollution } \\
\text { crisis }\end{array}$ & $\begin{array}{l}138 \\
(552)\end{array}$ & $\begin{array}{l}35 \\
(105)\end{array}$ & $\begin{array}{l}90 \\
(180)\end{array}$ & $\begin{array}{l}120 \\
(120)\end{array}$ & $957 / 383$ & 2.4 & $-\mathrm{V}$ \\
\hline & \multicolumn{6}{|l|}{ GRAND MEAN } & 2.44 & $-\mathrm{V}$ \\
\hline
\end{tabular}

Source: Field Survey Data 2021. 
Based on the benchmark used in the study, the response obtained as the answer to research question 2, on table 8 above, shows the total grand mean result of 2.44; which descriptively, indicates that "Oil firms' Interactive Relationship Marketing Approach" to oil pollution crisis has to a low extent, reduced the trend of kidnapping oil company workers in Niger Delta.

Table 9: To what extent does oil firms' "Responsive Relationship Marketing Approach" to oil pollution crisis reduced the trend of hostile demand of payment for oil spills damages in Niger Delta? $(\mathbf{n}=\mathbf{3 8 3})$

\begin{tabular}{|c|c|c|c|c|c|c|c|c|}
\hline & Question Items & $\mathrm{SA}$ & $\mathrm{A}$ & $\mathrm{D}$ & SD & TOTAL & $\mathrm{X}$ & DEC \\
\hline 1 & $\begin{array}{l}\text { To what extent does oil firms' } \\
\text { responsive relationship } \\
\text { marketing approach improved } \\
\text { its mutual relationship } \\
\text { marketing with the host } \\
\text { community. }\end{array}$ & $\begin{array}{l}115 \\
(460)\end{array}$ & $\begin{array}{l}95 \\
(285)\end{array}$ & $\begin{array}{l}43 \\
(86)\end{array}$ & $\begin{array}{l}130 \\
(130)\end{array}$ & $961 / 383$ & 2.5 & $+\mathrm{V}$ \\
\hline 2 & $\begin{array}{l}\text { Responsive relationship } \\
\text { marketing approach has to a } \\
\text { large extent encourage oil } \\
\text { spills crisis caused oil firms. }\end{array}$ & $\begin{array}{l}87 \\
(348)\end{array}$ & $\begin{array}{l}109 \\
(327)\end{array}$ & $\begin{array}{l}103 \\
(206)\end{array}$ & $\begin{array}{l}84 \\
(84)\end{array}$ & $965 / 383$ & 2.5 & $+\mathrm{V}$ \\
\hline 3 & $\begin{array}{l}\text { Oil firms' relationship } \\
\text { marketing orientation has not } \\
\text { been very useful to improve } \\
\text { responsive approach to oil } \\
\text { pollution crisis. }\end{array}$ & $\begin{array}{l}16 \\
(64)\end{array}$ & $\begin{array}{l}206 \\
(618)\end{array}$ & $\begin{array}{l}63 \\
(126)\end{array}$ & $\begin{array}{l}98 \\
(98)\end{array}$ & $906 / 383$ & 2.3 & $-\mathrm{V}$ \\
\hline 4 & $\begin{array}{l}\text { Responsive relationship } \\
\text { marketing approach has been } \\
\text { very proactive in the reduction } \\
\text { of oil-pollution crisis.. }\end{array}$ & $\begin{array}{l}105 \\
(420)\end{array}$ & $\begin{array}{l}53 \\
(159)\end{array}$ & $\begin{array}{l}178 \\
(356)\end{array}$ & $\begin{array}{l}47 \\
(47)\end{array}$ & $982 / 383$ & 2.5 & $+\mathrm{V}$ \\
\hline 5 & $\begin{array}{l}\text { Marketing orientation and } \\
\text { responsive relationship } \\
\text { marketing has to a large extent } \\
\text { failed to improve mutual } \\
\text { responsive approach of the oil } \\
\text { firms. }\end{array}$ & $\begin{array}{l}138 \\
(552)\end{array}$ & $\begin{array}{l}35 \\
(105)\end{array}$ & $\begin{array}{l}90 \\
(180)\end{array}$ & $\begin{array}{l}120 \\
(120)\end{array}$ & $957 / 383$ & 2.4 & $-\mathrm{V}$ \\
\hline & \multicolumn{6}{|l|}{ GRAND MEAN } & 2.44 & $-\mathrm{V}$ \\
\hline
\end{tabular}

Source: Field Survey Data 2021

Based on the benchmark used in the study, the response obtained as the answer to research question 3, on table 9 above, shows the total grand mean result of 2.44; which descriptively, indicates that "Oil firms' "Responsive Relationship Marketing Approach" to oil pollution crisis has to a low extent, reduced the trend of hostile demand of payment for oil spills damages in Niger Delta". 
Table 10: To what extent does oil firms' "Reactive Relationship Marketing Approach" to oil pollution crisis reduced the trend of government hostile attack on the host communities by soldiers in Niger Delta? $(n=383)$

\begin{tabular}{|c|c|c|c|c|c|c|c|c|}
\hline & & SA & A & $\mathrm{D}$ & SD & TOTAL & $\mathrm{X}$ & DEC \\
\hline 1 & $\begin{array}{l}\text { To a large extent, reactive } \\
\text { marketing approach of the } \\
\text { oil firms in Niger Delta has } \\
\text { promote effective oil } \\
\text { pollution crisis } \\
\text { management to avoid } \\
\text { hostile attack by } \\
\text { government }\end{array}$ & $\begin{array}{l}79 \\
(316)\end{array}$ & $\begin{array}{l}133 \\
(399)\end{array}$ & $\begin{array}{l}49 \\
(98)\end{array}$ & $\begin{array}{l}122 \\
(122)\end{array}$ & $935 / 383$ & 2.4 & $-\mathrm{V}$ \\
\hline 2 & $\begin{array}{l}\text { Reactive relationship } \\
\text { marketing orientation by oil } \\
\text { firms in Niger Delta has to } \\
\text { a large extent justifies a } \\
\text { proactive control } \\
\text { measure on oil pollution } \\
\text { Crisis. }\end{array}$ & $\begin{array}{l}110 \\
(440)\end{array}$ & $\begin{array}{l}114 \\
(342)\end{array}$ & $\begin{array}{l}50 \\
(100)\end{array}$ & $\begin{array}{l}109 \\
(109)\end{array}$ & $991 / 383$ & 2.5 & $+\mathrm{V}$ \\
\hline 3 & $\begin{array}{l}\text { The use of inefficient } \\
\text { reactive relationship } \\
\text { marketing approach } \\
\text { has to a large extent } \\
\text { promote weak relationship } \\
\text { design. }\end{array}$ & $\begin{array}{l}64 \\
(256)\end{array}$ & $\begin{array}{l}96 \\
(288)\end{array}$ & $\begin{array}{l}103 \\
(206)\end{array}$ & $\begin{array}{l}120 \\
(120)\end{array}$ & $870 / 383$ & 2.2 & $-\mathrm{V}$ \\
\hline 4 & $\begin{array}{l}\text { Reactive relationship } \\
\text { marketing orientation by oil } \\
\text { firms in Niger Delta has not } \\
\text { been helpful to prevent oil } \\
\text { pollution crisis. }\end{array}$ & $\begin{array}{l}115 \\
(460)\end{array}$ & $\begin{array}{l}83 \\
(249)\end{array}$ & $\begin{array}{l}64 \\
(128)\end{array}$ & $\begin{array}{l}121 \\
(121)\end{array}$ & $958 / 383$ & 2.5 & $+\mathrm{V}$ \\
\hline 5 & $\begin{array}{l}\text { The accuracy of reactive } \\
\text { approach by oil firms has to } \\
\text { a large extent been very } \\
\text { active to reduce oil } \\
\text { pollution crisis. }\end{array}$ & $\begin{array}{l}191 \\
(764)\end{array}$ & $\begin{array}{l}33 \\
(99)\end{array}$ & $\begin{array}{l}59 \\
(118)\end{array}$ & $\begin{array}{l}100 \\
(100)\end{array}$ & $1081 / 383$ & 2.8 & $+\mathrm{V}$ \\
\hline \multicolumn{7}{|c|}{ GRAND MEAN } & 2.48 & $-\mathrm{V}$ \\
\hline
\end{tabular}

Source: Field Survey Data 2021

Based on the benchmark used in the study, the response obtained as the answer to research question 4, on table 10 above, shows the total grand mean result of 2.48; which descriptively, indicates that "Oil firms' "Reactive Relationship Marketing Approach" to oil pollution crisis has to a low extent, reduced the trend of government hostile attack on the host communities by soldiers in Niger Delta. 


\section{Test of Hypotheses}

\section{Test of Hypothesis 1:}

Ho1 Oil firms" “Adaptive Relationship Marketing Approach" to oil pollution crisis does not, significantly reduced the trend of oil facility destruction in Niger Delta.

$\mathbf{H}_{\text {A1 }}$ Oil firms' "Adaptive Relationship Marketing Approach" to oil pollution crisis has significantly reduced the trend of oil facility destruction in Niger Delta.

Table 11: Summary of Response Frequency Obtained for Research Question 1.

\begin{tabular}{|l|l|l|l|l|l|l|}
\hline $\begin{array}{l}\text { Response Index to Question: } \\
5\end{array}$ & \multicolumn{2}{l}{3} & \multicolumn{3}{l|}{3} \\
\hline X: TOTAL AGREE: (SA+A) & 745 & 675 & 682 & 579 & 657 \\
\hline Y: TOTAL DISAGREE: (D+SD) & 216 & 290 & 224 & 403 & 300 \\
\hline
\end{tabular}

Table 12: Statically Computed Response Values

\begin{tabular}{|l|l|l|l|l|l|}
\hline & $\mathbf{X}$ & $\mathbf{Y}$ & $\mathbf{X}^{\mathbf{2}}$ & $\mathbf{Y}^{\mathbf{2}}$ & $\mathbf{X Y}$ \\
\hline & $\mathbf{7 4 5}$ & $\mathbf{2 1 6}$ & 555,025 & 46,656 & 160,920 \\
\hline & $\mathbf{6 7 5}$ & $\mathbf{2 9 0}$ & 455,625 & 84,100 & 195,750 \\
\hline & $\mathbf{6 8 2}$ & $\mathbf{2 2 4}$ & 465,124 & 50,176 & 152,768 \\
\hline $\mathbf{5 7 9}$ & $\mathbf{4 0 3}$ & 335,241 & 162,409 & 233,337 \\
\hline & $\mathbf{6 5 7}$ & $\mathbf{3 0 0}$ & 231,649 & 90,000 & 197,100 \\
\hline \multicolumn{2}{|l}{ TOTAL: $\mathbf{3 , 3 3 8}$} & $\mathbf{1 , 4 3 3}$ & $\mathbf{2 , 2 4 2 , 6 6 4}$ & $\mathbf{4 3 3 , 3 4 1}$ & $\mathbf{9 3 9 , 8 7 5}$ \\
\hline
\end{tabular}

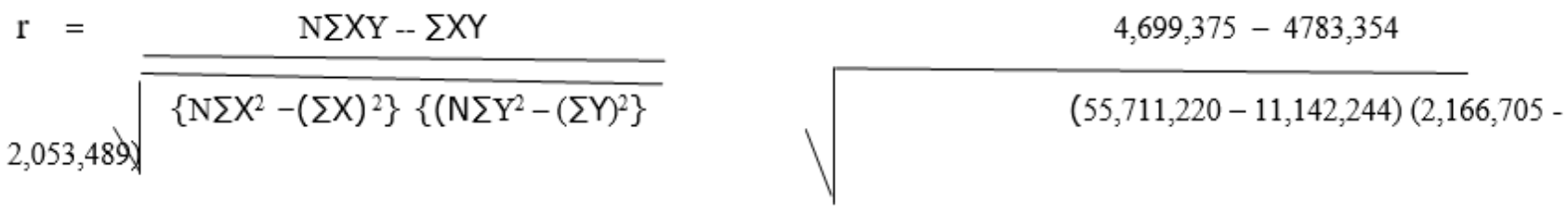

$71,076 \times 2,645,886$

$-83,979$

188058,993336

$\frac{-83,979}{433657} \quad \mathbf{r}=-\mathbf{0 . 1 9}$

$\mathrm{t}=\mathrm{r} \sqrt{\frac{\mathrm{n}-2}{1-\mathrm{r}^{2}}} \quad=-0.19 \sqrt{\frac{5-2}{1-(-0.19)^{2}}}$

$=-0.19 \sqrt{\frac{5-2}{1-(-0.19)^{2}}}=-0.19 \sqrt{1-(-0.19)^{2}}=-0.19 \times 1.76=\mathbf{t}=\mathbf{- 0 . 3 3}$ 


\section{Decision Rule:}

Reject Ho if the computed $t$ value is greater than the critical (table) value of 3.182; otherwise accept the null hypothesis.

\section{Decision Point:}

Since the computed t- value of $\mathbf{- 0 . 3 3}$ is less than the critical (table) value of $t$ (3.182), the null hypothesis is taken and the alternative hypothesis Ha1 rejected. This reveals that "Oil firms' Adaptive Relationship Marketing Approach to oil pollution crisis does not, significantly reduced the trend of oil facility destruction in Niger Delta".

\section{Hypothesis Test: 2}

Ho2 Oil firms' "Interactive Relationship Marketing Approach" to oil pollution crisis does not, significantly reduced the trend of kidnapping oil company workers in Niger Delta.

$\mathbf{H}_{\mathrm{A2}}$ Oil firms" "Interactive Relationship Marketing Approach" to oil pollution crisis has significantly reduced the trend of kidnapping oil company workers in Niger Delta.

Table 13: Summary of Response Frequency Obtained from Research Question 2

\begin{tabular}{|ll|l|l|l|l|l|}
\hline \multicolumn{2}{|l|}{ Response Index to Question: } & 1 & 2 & 3 & 4 \\
\hline X: TOTAL AGREE: (SA+A) & 715 & 782 & 544 & 709 & 863 \\
\hline Y: TOTAL DISAGREE: (D+SD) & 220 & 309 & 326 & 249 & 239 \\
\hline
\end{tabular}

Table 14: Statically Computed Response Values

\begin{tabular}{|l|l|l|l|l|l|}
\hline \multicolumn{2}{|c|}{$\mathbf{X}$} & $\mathbf{Y}$ & $\mathbf{X}^{\mathbf{2}}$ & $\mathbf{Y}^{\mathbf{2}}$ & $\mathbf{X Y}$ \\
\hline & 715 & 220 & 543169 & 44521 & 155,507 \\
\hline & 782 & 309 & 432964 & 81796 & 188,188 \\
\hline & 544 & 326 & 698896 & 58564 & 202,312 \\
\hline & 709 & 249 & 469225 & 45796 & 146,590 \\
\hline & 863 & 239 & 241081 & 49284 & 109,002 \\
\hline TOTAL: $\mathbf{3 , 6 1 3}$ & $\mathbf{1 , 3 4 3}$ & $\mathbf{2 , 3 8 5 , 3 3 5}$ & $\mathbf{2 7 9 , 9 6 1}$ & $\mathbf{8 0 1 , 5 9 9}$ \\
\hline
\end{tabular}




$$
\begin{aligned}
& r=\frac{N \Sigma X Y-\Sigma X Y}{\sqrt{\left\{N \Sigma X^{2}-(\Sigma X)^{2}\right\}\left\{\left(N \Sigma Y^{2}-(\Sigma Y)^{2}\right.\right.}} \quad \sqrt{(11,926,675-11,607,649)(1399805-1380625)} \\
& \sqrt{319,026 \times 19180} \quad \sqrt{6118918680} \\
& \frac{4770}{78223.52}=\mathbf{r}=\mathbf{- 0 . 0 6 1} \\
& \mathrm{t}=\mathrm{r} \sqrt{\frac{\mathrm{n}-2}{1-\mathrm{r}^{2}}} \quad=-0.061 \sqrt{\frac{5-2}{0.003721}} \\
& =-0.061 \sqrt{\frac{3}{0.003721}}=-0.061 \times 28.394=\mathbf{t}=\mathbf{- 1 . 7 3 2}
\end{aligned}
$$

\section{Decision Rule:}

Reject Ho if, the computed $t$ value is greater than the critical (table) value of 3.182 ; otherwise accept the null hypothesis.

\section{Decision Point:}

Since the computed t- value of $\mathbf{- 1 . 7 3 2}$ is less than the critical (table) value of $t$ (3.182), the null hypothesis is taken and the alternative hypothesis Ha1 rejected. This reveals that "Oil firms' "Interactive Relationship Marketing Approach to oil pollution crisis does not, significantly reduced the trend of kidnapping oil company workers in Niger Delta".

\section{Hypothesis Test: 3}

Ho3 Oil firms' "Responsive Relationship Marketing Approach" to oil pollution crisis does not,

significantly reduced the trend of hostile demand for payment of oil spills damages in Niger Delta.

$\mathbf{H}_{\mathrm{A3}}$ Oil firms" "Responsive Relationship Marketing Approach" to oil pollution crisis has significantly reduced the trend of hostile demand for payment of oil spills damages in Niger Delta. 
Table 15: Summary of Response Frequency Obtained from Research Question 3.

\begin{tabular}{|l|l|l|l|l|l|l|}
\hline $\begin{array}{l}\text { Response Index to Question: } \\
5\end{array}$ & \multicolumn{3}{l}{3} & \multicolumn{3}{l}{3} \\
\hline X: TOTAL AGREE: (SA+A) & 779 & 700 & 418 & 575 & 533 \\
\hline Y: TOTAL DISAGREE: (D+SD) & 228 & 303 & 259 & 231 & 239 \\
\hline
\end{tabular}

Table 16: Statically Computed Response Values

\begin{tabular}{|l|l|l|l|l|l|}
\hline \multicolumn{2}{|c|}{$\mathbf{X}$} & $\mathbf{Y}$ & $\mathbf{X}^{\mathbf{2}}$ & $\mathbf{Y}^{\mathbf{2}}$ & $\mathbf{X Y}$ \\
\hline & $\mathbf{7 7 9}$ & $\mathbf{2 2 8}$ & 543169 & 44521 & 155,507 \\
\hline & $\mathbf{7 0 0}$ & $\mathbf{3 0 3}$ & 432964 & 81796 & 188,188 \\
\hline & $\mathbf{4 1 8}$ & $\mathbf{2 5 9}$ & 698896 & 58564 & 202,312 \\
\hline & $\mathbf{5 7 5}$ & $\mathbf{2 3 1}$ & 469225 & 45796 & 146,590 \\
\hline & $\mathbf{5 3 3}$ & $\mathbf{2 3 9}$ & 241081 & 49284 & 109,002 \\
\hline TOTAL: & $\mathbf{3 , 0 0 5}$ & $\mathbf{1 , 2 6 0}$ & $\mathbf{2 , 3 8 5 , 3 3 5}$ & $\mathbf{2 7 9 , 9 6 1}$ & $\mathbf{8 0 1 , 5 9 9}$ \\
\hline
\end{tabular}

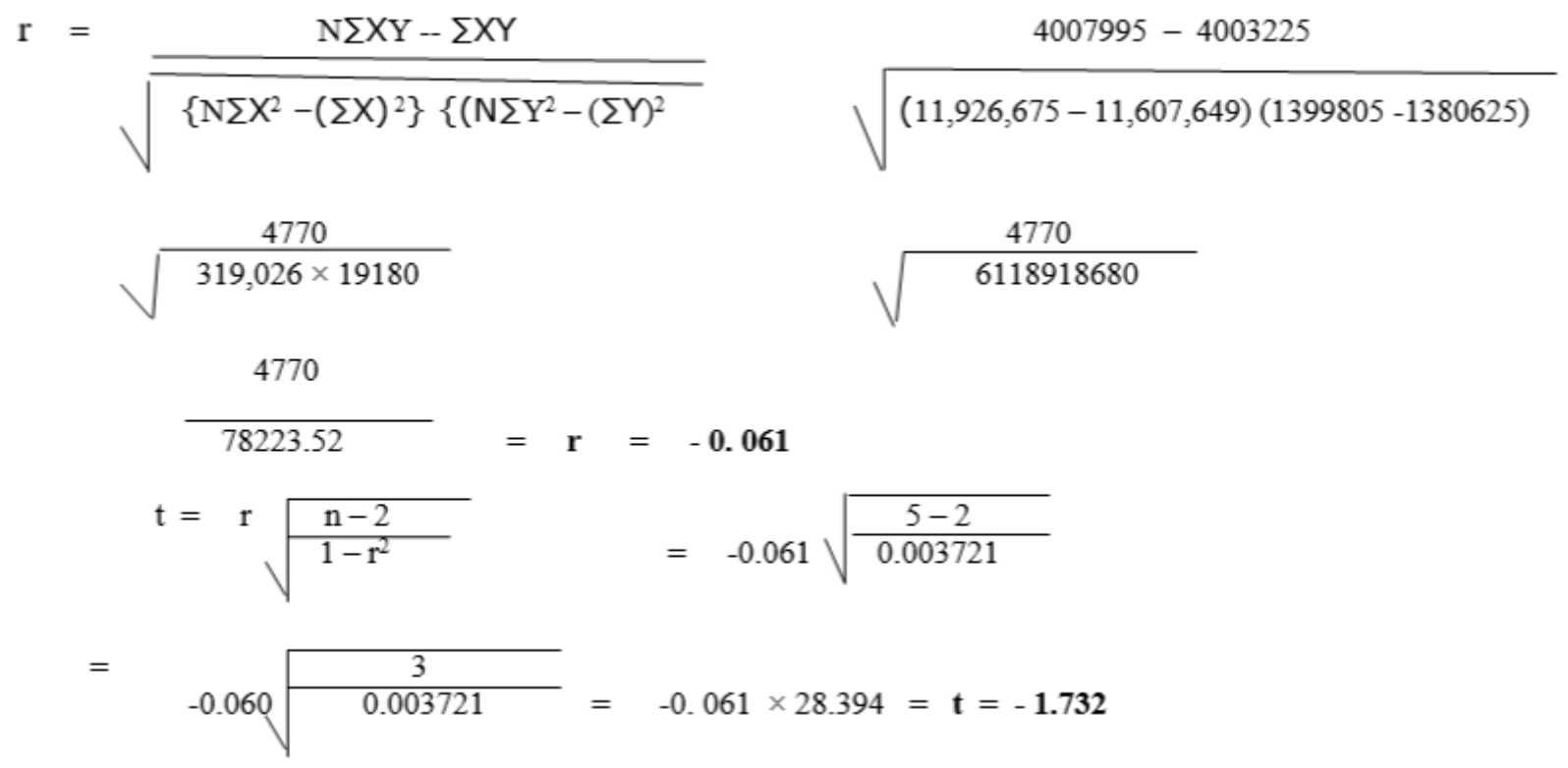

\section{Decision Rule:}

Reject Ho if the computed t value is greater than the critical (table) value of 3.182; otherwise accept the null hypothesis.

\section{Decision Point:}

Since the computed t-value of $\mathbf{- 1 . 7 3 2}$ is less than the critical (table) value of $\mathbf{t}$ (3.182), the null hypothesis is taken and the alternative hypothesis $\mathrm{Ha}_{1}$ rejected. This reveals that "Oil 
firms' "Responsive Relationship Marketing Approach to oil pollution crisis does not, significantly reduced the trend of hostile demand for payment of oil spills damages in Niger Delta".

\section{Hypothesis Test: 4}

Ho4 Oil firms" "Reactive Relationship Marketing Approach" to oil pollution crisis, does not significantly reduced government hostile attack on the host community by soldiers in Niger Delta.

$\mathbf{H}_{\mathbf{A} 4}$ Oil firms" "Reactive Relationship Marketing Approach" to oil pollution crisis, has significantly reduced government hostile attack on the host community by soldiers in Niger Delta.

Table 17: Summary of Response Frequency Obtained for Research Question 4.

\begin{tabular}{|l|l|l|l|l|l|}
\hline $\begin{array}{l}\text { Response Index to Question: } \\
5\end{array}$ & \multicolumn{1}{l}{1} & 3 \\
\hline X: TOTAL AGREE: (SA+A) & 745 & 675 & 682 & 579 & 657 \\
\hline Y: TOTAL DISAGREE: (D+SD) & 216 & 290 & 224 & 403 & 300 \\
\hline
\end{tabular}

Table 18: Statically Computed Response Values

\begin{tabular}{|l|l|l|l|l|l|}
\hline \multicolumn{2}{|c|}{$\mathbf{X}$} & $\mathbf{Y}$ & $\mathbf{X}^{\mathbf{2}}$ & $\mathbf{Y}^{\mathbf{2}}$ & $\mathbf{X Y}$ \\
\hline & $\mathbf{7 4 5}$ & $\mathbf{2 1 6}$ & 555,025 & 46,656 & 160,920 \\
\hline & $\mathbf{6 7 5}$ & $\mathbf{2 9 0}$ & 455,625 & 84,100 & 195,750 \\
\hline & $\mathbf{6 8 2}$ & $\mathbf{2 2 4}$ & 465,124 & 50,176 & 152,768 \\
\hline & $\mathbf{5 7 9}$ & $\mathbf{4 0 3}$ & 335,241 & 162,409 & 233,337 \\
\hline & $\mathbf{6 5 7}$ & $\mathbf{3 0 0}$ & 231,649 & 90,000 & 197,100 \\
\hline TOTAL: & $\mathbf{3 , 3 3 8}$ & $\mathbf{1 , 4 3 3}$ & $\mathbf{2 , 2 4 2 , 6 6 4}$ & $\mathbf{4 3 3 , 3 4 1}$ & $\mathbf{9 3 9 , 8 7 5}$ \\
\hline
\end{tabular}




$$
\begin{aligned}
& r=\quad \mathrm{N} \Sigma X Y-\Sigma X Y \quad 4,699,375-4783,354
\end{aligned}
$$

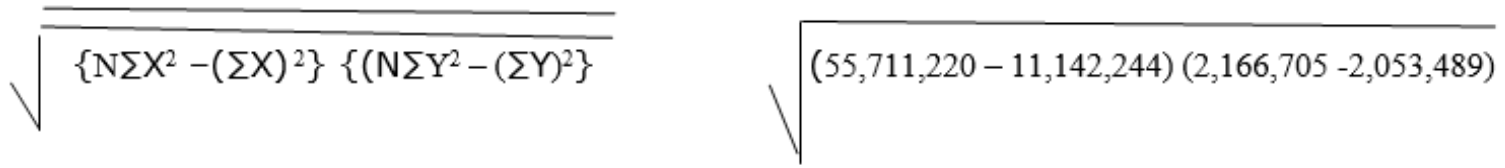

$$
\begin{aligned}
& \sqrt{71,076 \times 2,645,886} \\
& \frac{-83,979}{433657} \quad \mathbf{r}=-\mathbf{0 . 1 9} \\
& \mathrm{t}=\mathrm{r} \sqrt{\frac{\mathrm{n}-2}{1-\mathrm{r}^{2}}}=-0.19 \sqrt{\frac{5-2}{1-(-0.19)^{2}}} \\
& =\quad-0.19 \sqrt{\frac{5-2}{1-(-0.19)^{2}}}=-0.19 \sqrt{1-(-0.19)^{2}}=-0.19 \times 1.76=\mathbf{t}=-\mathbf{0 . 3 3}
\end{aligned}
$$

\section{Decision Rule:}

Reject Ho if the computed t value is greater than the critical (table) value of 3.182; otherwise accept the null hypothesis.

\section{Decision Point:}

Since the computed t- value of $\mathbf{- 0 . 3 3}$ is less than the critical (table) value of $t$ (3.182), the null hypothesis is taken and the alternative hypothesis Ha1 rejected. This reveals that 'Oil firms' adaptive, interactive, responsive, reactive Relationship Marketing Approach to oil pollution crisis, does not significantly reduced government hostile attack on the host community by soldiers in Niger Delta".

\section{DISCUSSION OF FINDINGS}

As obtained from evidence of descriptive statics results of this study, the total grand mean result of $2.44,2.44,2.44$, and 2.48 in table $7,8,9$ and 10 respectively; descriptively indicates that 'Oil firms' (adaptive, responsive, interactive and reactive Relationship Marketing Approach" to oil pollution crisis has to a low extent, reduced the trend of oil facility destruction, kidnapping oil company workers, hostile demand for payment of oil spills damages, and government hostile attack on the host communities by soldiers respectively - in Niger Delta. This means that the relationship marketing approaches employed by the oil firms were not only inactive enough to reduce oil pollution crisis, but inefficiently guided. The inefficient approaches of the adaptive, responsive, interactive and reactive techniques employed could not create significant reduction of oil pollution crisis in Niger Delta. The computed grand mean result in table 7 to 10 respectively reveals that the adaptive, 
responsive, interactive and reactive relationship marketing approaches have to a "low extent" conformed with the hypothesis test result that "Oil firms' Adaptive Relationship Marketing Approach, Interactive Relationship Marketing Approach, Responsive Relationship Marketing Approach and Reactive Relationship Marketing Approach to oil pollution crisis does not, significantly reduced the trend of oil facility destruction, the trend of kidnapping oil company workers, the trend of hostile demand for payment of oil spills damages, and government hostile attack on the host community by soldiers respectively, in Niger Delta".

In addition, the descriptive and influential results deduced as answers to the research questions and the test result of the hypotheses separately confirms the empirical findings, and observations deduced from theoretical underpinnings to the review of related literature in Gabriel (2017), Fayifu, (2006); Onuoha (2007); and Okoh (2009) who in separate views confirmed the content validity of the result with the view that: "Oil firms operating in Niger Delta are usually susceptible or vulnerable to socio-economic crisis caused by incessant oil spillages and gas flaring activities in the oil-bearing community". The operating attitudes of oil firms were stimulated by the high degree of unwanted political gambits employed to drive their relationship marketing approach to oil pollution crisis in Niger Delta.

This finding agreed with those of researchers in Udu (2007), Sauka and Oshita (2007), and Benconi (2010), who found that oil spills and gas flaring activities that resulted in oil pollution crisis was traced to inefficient application of the approach, lack of mutual trust, and sluggish adoption of the responsive, interactive, proactive and reactive marketing relationship approach to oil pollution crisis.

In addition, this finding was consistent with the review of related literature which strongly emphasize that, incessant oil pollution occurrence that destroys the fecund agricultural land, the marine source of livelihood of the host community, quality air and their health wellbeing were traced to be the major causes of the oil pollution crisis (Benconi, 2010); and Koateh and Menele, 2007). The implication of the finding of this study was identified to the oil firms' failure to reduced oil pollution crisis, which if no pragmatic improvements measures are not adopted in a responsible manner, more adverse or harmful consequences on the relationship marketing practice of the oil firms will serve as a threat to the wellbeing of the oil firms in its host communities.

\section{CONCLUSION}

This study examined the extent to which the multinational oil firms' relationship marketing approach to oil pollution crisis has reduced the trend of violent Crisis in Niger Delta. The study finds out that the extent to which, relationship marketing approach of the oil firms has reduce the trend of oil pollution crisis in Niger Delta with the use of interactive, responsive, proactive and reactive relationship approach was low enough to create significant improvement. Based on the data collected, analyzed and interpreted, the study scientifically reveals that 'Oil firms' Adaptive Relationship Marketing Approach, Interactive Relationship Marketing Approach, Responsive Relationship Marketing Approach and Reactive Relationship Marketing Approach to oil pollution crisis does not, significantly reduced the trend of oil facility destruction, the trend of kidnapping oil company workers, the trend of 
hostile demand for payment of oil spills damages, and government hostile attack on the host community by soldiers respectively in Niger Delta".

Similarly, evidence of government inaction to issues of oil spills and constant gas flaring activities, was identified capable of destroying fecund agricultural farmlands, marine source of livelihood and quality air are also major factors considered responsible for ineffective relationship marketing approach and oil pollution crisis in Niger Delta.

In line with this, it was concluded that the seeming endless involvement of oil firms in oil pollution, was responsible for the low degree of relationship marketing between the oil firms and its host communities; evidenced in the failure to avoid oil facility destruction, kidnapping oil company workers, continuous hostile demand for payment of oil spills damages, and government hostile attack on the host community by soldiers were key factors responsible for oil pollution crisis in Niger Delta. This suggests that the more frequent the occurrence of oil spills crisis the more harmful the consequences and oil pollution crisis in oil-bearing communities; which if not given pragmatic attention, more harm than good will be recorded in the host community.

\section{RECOMMENDATIONS}

Based on the findings obtained from this study, the following recommendations were deduced.

1. The oil firms should establish "Relationship Marketing Responsibility Unit (RMRU)", in the marketing department of the firm to address all oil pollution related crisis using adaptive marketing technique that will enable the oil firms to adapt responsible relationship marketing in dealing with oil pollution crisis resulting from issues on the oil facility destruction in Niger Delta. This will help to enable oil firms to use adapt relationship marketing approach to enhance their responsible relationship marketing practice.

2. Oil firms should also establish “Quality Interactive Relationship Services Solution Center (QIRSSC)" in the marketing department of the oil firms to oversee all issues concerning oil pollution crisis in the host community. This will help oil firms to protect their relationship marketing practice in a bid to avoid kidnapping of oil company workers in Niger Delta.

3. It is also advisable that the multinational oil producing firms should build "Oil Spills Crisis Response Center (OPCRC)", in each of the Local Government Areas in Niger Delta to deal with all oil pollution related problems and its resultant crisis capable of causing hostile demand for payment of oil spills damages. This will help reduce related oil pollution crisis situations in the oil-bearing community.

4. In addition, oil firms should formulate "Reactive Relationship Marketing Policy (RRMP)" to oversee issues oil pollution crisis that resulting in government hostile attack on the host communities by soldiers in Niger Delta. This will help to enable the oil firms to use reactive relationship marketing approach to reduce the increasing trend of oil pollution in a responsible manner. 


\section{REFERENCES}

Aakol, K. G. (2009). Niger-Delta Sustainable Development as a Strategy for Conflict Prevention: The case of Environmental Pollution in Niger Delta. Vico Publishers.

Adujui, S.O. (2017). Oil companies and oil pollution issues in oil-bearing communities: The position of indigenes in Niger Delta. Journal of Corporate Management, 2(2); 51-59.

Akinbuwa, E . F. (2008). Niger Delta oil spills crisis and development in oil-bearing communities. International Journals of Environmental Studies 11(2); 89-97.

Akpan, F. (2005, July 10). Oil spills: the root of oil crisis in Niger Delta. The Punch.

Akpan, J. D. (2005). Ethnic militancy and the Nigerian state. Journal of International Politics and Development Studies, 2(2) 20-27.

Amadi, Y. N; \& Nwomaji, B. S. (2008). SPDC and EF Oil Companies: The position of the locals in Niger Delta. Nigerian Journal of Corporate Management, 2(3); 60-69.

Ani, I. P. (2012). Research Methodology for Social and Management Sciences. Kenton Publishers.

Asakitikpi, E. A; \& Oyelavan, A. P. (2006). Oil extraction and its socio-cultural impact on people in Niger Delta, a paper presented at the $4^{\text {th }}$ Annual Conference of Environmental Protection Society of Nigeria.

Atatow, R.E; \& Gannon, A. (1982). Corporate responsibility and sustainability marketing. Journal of Marketing and Public Policy.2(2); 23-28.

Baanu, C.E.; \& Gonee, F.O.(2019). Oil pollution and socio-economic impact in Niger Delta. Journal of Environmental and Economic Research, 2(1); 73-81.

Bomi, Z. (2010). Conflict resolution, oil pollution crisis and development in Africa. Mattheouse Press Ltd.

Briggs, M. P. (2007). Oil pollution Crisis and Environmental Degradation in Niger Delta. , Journal of Marketing 53(2);44 -50.

Chukwu, I. (2008). Corporate responsibility and sustainable growth in the Niger Delta, Journal of marketing and Public Policy.2(2); 23-28.

Cohen, B. E; \& Swerdlik, L. L. (2010). Practical approach to research methodology. Gaman Publishers.

Doma, B.V; \& Kooateh, D. (2018). Oil for nothing: multinational corporations, environmental destruction, death and impurity in the Niger Delta, Journal of Environment Management. 3(1) 93-100.

Donneh, S. R. (1984). Oil pollution crisis and economic impact in Niger Delta. Journal of Environmental and Economic Research, 3(1); 83-92.

Dukun, G. (2008). Environmental management and the society's interest, Journal of Marketing 53(2);34- 40.

Ekpu, B. (2010). Environmental pollution in the Niger Delta: An economic perspective, International Conference on the Nigeria State, Oil Industry and the Niger Delta, pp 131-137.

Esedwuo, N. P. (2008). Environmental destruction and the place of oil firms in Niger Delta. Journal of Environmental Research 1(2); 37-42.

Fayifu, T. (2006). Women environment and food production: The challenge of the Niger Delta. Journal of Environment Management 2(2); 72-80.

Funiwa, F. Y. (2002). Oil firms position and, environmental destruction in the Niger Delta. Journal of Sustainable Environmental Management. 3(1) 93-100.

Gabriel, A. I. (2017, November, 12). Ogoni struggle continues in Geneva conference: World Council of Chambers and African Council of Churches Conference. The Guardian. 
Grace, A. \& Cohen, B. E. (2011). Oil for sorrow in Niger Delta. Journal of Environmental Ecological Research 1(2); 37-42.

Hegbataama, G.E. (2011). Environmental marketing and food security in Delta State. Nigerian Journal of Marketing Research, 2(7); 162-168.

Hegbataama, S. A. (2011, August 10). Danger of oil pollution and poverty in Niger Delta. The National Network.

Iba, C.O. (2013). Oil pollution: the multinational corporations and environmental issues in Niger Delta. Journal of Economic Research 1(2); 37-42.

Koateh, E, V. and Menele, S. (2007). Multinational oil companies and environmental degradation in Bayelsa State. Nigerian Journal of Corporate Management 3(2); 43-48.

Kotler, P. (1980). Marketing Management. prentice Hall Inc.

Kotler, P. (2000). Marketing Management: Millennium Edition. Prentice-Hall.

Miller, L. (2007). Niger Delta crisis: The effect on Nigeria economy. International conference on the Niger Delta state, Oil Industry and Niger Delta; PP 362-367.

Mohammed, J. F. (2008), The state and the society economy Niger Delta. Human Security Journal 1(3); 26-36.

Morgan, I. J; \& Russug, O. (2000). Where Vultures Feast: Forty Years of Shell in Niger Delta, Ibadan: Kraft Books Limited.

Norharus, R. (2011). Multinational corporations and environmental crisis in Niger Delta. Nigeria Journal of Environmental Research 1(2); 37-42.

Nwomaji, E. R. (2008). Environmental crisis and relationship marketing in Niger Delta. Journal of Human and Environmental Research 1(3); 39-45.

Obi, C. (2010). Environmental conflicts and nigeria national security: reunification of the ecology- security nexus for the sub-regional peace. Journal of Environment Ecology Management. 1(3); 31- 40.

Okoh, G.E. (2009). The environment and food security in Delta State. Nigerian Journal of marketing Research, 2(7); 162-168.

Okon, D.R. (2006). Environmental pollution in the niger delta: the impact on human health and the society, paper presented at 3rd International Conference on Petroleum Industry in Nigeria, Port Harcourt. $20^{\text {th }}$ July, 1985.

Omonona, B.T. (2001). "Causes and effects of socio-economic poverty in oil-producing states of Niger Delta", International Journal of Environment Studies 11(2); 99-106.

Onkisit, F; \& Shaw, R. N. (2001). Niger Delta environment and natural disaster. International conference on state, oil industry and the Niger Delta. Harley Publications.

Onuoha, F. C. (2008). Oil Exploitation, Environmental Degradation and Climate Change: Assessing the Vulnerability of the Niger Delta Environment to Natural Disaster. International Conference on state, oil Industry and the Niger Delta, Port Harcourt: Harley Publications.

Osabie, A. (2007). Managing Multiple Minority Problems in a Divided Society: The Nigerian experience in Niger Delta, Journal of Modern African Studies 36(4); 22-28.

Osaghae, D. S. (2007). Niger Delta sitting on environmental time bomb. Journal of National Standard. 2 (19); 32-43.

Osajui, E.O. (2011). Environmental degradation in Nigeria Niger Delta: The causes and effects. Journal of Environmental and Economic Research, (1)2, 53-59.

Perrault, W .D. and McCarthy, E.(1999). Basic Marketing: Global Managerial Approach. $13^{\text {th }}$ Ed. Irwin McGraw-Hill. 
Romiyu, D; \& Dobayima, F. O. (2019). Niger Delta Environment and Ecological Disaster. International Conference on state, oil industry and the Niger Delta, Harley Publications.

Sapru, R. K. (2009), Administrative Theories and Management. Thought: New Delhi, PHI Learning. Private Limited.

Sauka, J.A; and Oshita, O. (2007). Impact of Oil Exploration on Economic Poverty in Rivers State Nigerian Journal of Environmental and Economic Research, 2(1); 81-90.

Sohiffman, L. G; and Kanuk, L. L. (2009).Consumers Behaviour. $9^{\text {th }}$ edition, Pearson Education Hall.

Tuyizere, A. P. (2007). Women and Agricultural Development in Niger Delta. Kampula, Makarere Ibadan University press.

Uba, (2002). Crisis in the Oil-producing Communities in Nigeria, Journal of human Ecology 16(3) 201- 216.

Udu, C. T. I. (2007). The Oil Industry and the Environment: The Nigerian Account, Journal of Institute of Petroleum. 58(1) 201-208.

Ukaogo, O. (2007).Poverty in Niger Delta oil-producing community. Benson and sons Publishers.

Utukepo, A.C. (2011). Essentials of Environmental Issues: The World and Nigeria in Perspective. Daily Graphics Publications.

Uzoagulu, A.E. (2002). Practical Guide to Working Research Projects in Tertiary Institutions. John Jacob's Classic Publishers Ltd.

Vigale, D; \& Nenu, B.Y. (2006). Impact of oil pollution on food production and economic poverty in Rivers State. Nigeria Journal of Environmental Research (1)2; 57-62.

Willims, R. M. S. (2000). Marketing Management. Butter-Worth Heinemann. 